\title{
Management and valorisation of wastes through use in producing alkali-activated cement materials
}

\author{
Susan A. Bernal, ${ }^{1,2}$ Erich D. Rodríguez, ${ }^{3}$ Ana Paula Kirchheim, ${ }^{3}$ John L. Provis ${ }^{1 *}$ \\ ${ }^{1}$ Department of Materials Science and Engineering, The University of Sheffield, Sir \\ Robert Hadfield Building, Mappin St, Sheffield S1 3JD, United Kingdom \\ ${ }^{2}$ Department of Civil and Structural Engineering, The University of Sheffield, Sir \\ Frederick Mappin Building, Mappin St, Sheffield S1 3JD, United Kingdom \\ ${ }^{3}$ Nucleo Orientado para a Inovação da Edificação, NORIE, Universidade Federal do \\ Rio Grande do Sul, Porto Alegre, RS, Brazil \\ ()

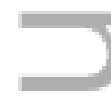 \\ *corresponding author. j.provis@sheffield.ac.uk
}

\begin{abstract}
There is a growing global interest in maximising the re-use and recycling of waste, to minimise the environmental impacts associated with waste treatment and disposal. Useof high-volume wastesin the production of blended or novel cements (including alkali-activated cements) is well known as a key pathway by which these wastes can be re-used. This paper presents a critical overview of the urban, agricultural, mining and industrial wastes that have been identified as potential precursors for the production of alkali-activated cement materials, or that can be effectively stabilised/solidified via alkali activation, to assure their safe disposal. Thecentralaim of this review is to elucidate the potential advantages and pitfalls associated with the application of alkali-activation technology to a wide variety of wastes that have been claimed to be suitable for the production of construction materials. A brief overview ofthe generation and characteristics ofeach waste is reported, accompanied by identification ofopportunitiesforthe use of alkali-activation technology for their valorisation and/ormanagement.
\end{abstract}

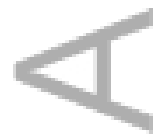

This is the author manuscript acceptedl for publication and has undergone full peer review but has not been through the copyediting, typesetting, pagination and proofreading process, which may lead to differences between this version and the Version of Record. Please cite this article as doi: $10.1002 /$ jctb.4927

This article is protected by copyright. All rights reserved. 
Keywords:Engineering; Immobilisation; Clean processes; Recycling; Waste treatment and waste minimisation

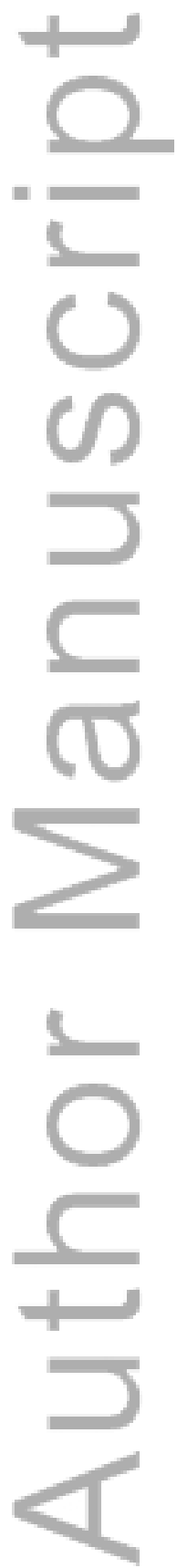

This article is protected by copyright. All rights reserved. 


\section{Contents}

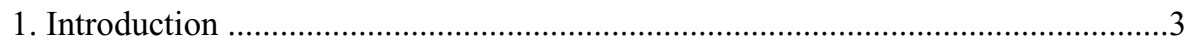

2. Urban wastes

2.1. Ashes from municipal solid waste incineration............................

2.2. Ceramic and demolition wastes.................................................. 11

2.3. Wastes or sediments from water treatment plants..........................15

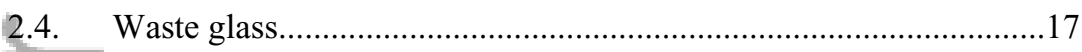

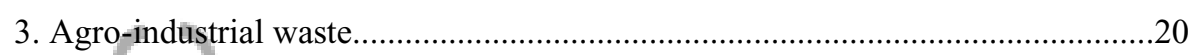

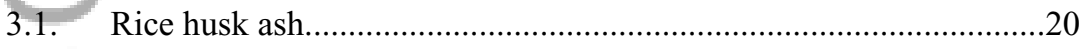

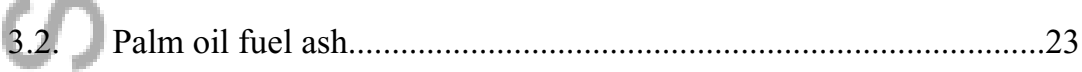

3.3. Sugar cane bagasse ashes.......................................................25

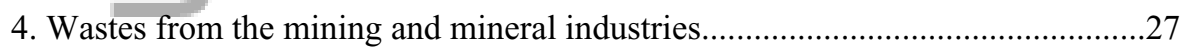

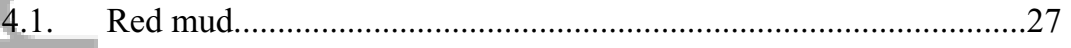

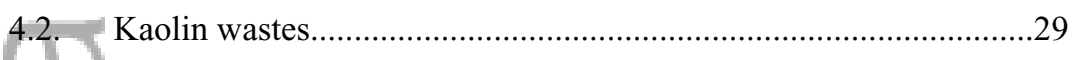

4.3. Low purity clays.......................................................................

4.4. Other mining and mineral wastes................................................32

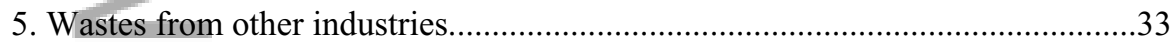

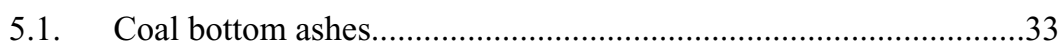

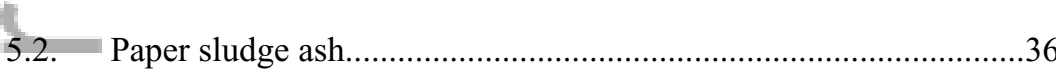

5.3. Spent fluid catalytic cracking catalyst....................................... 37

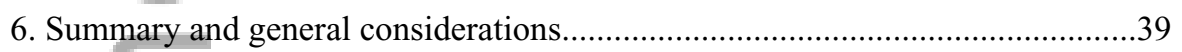

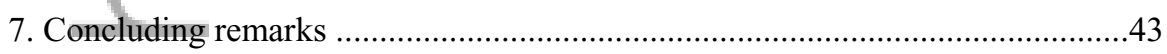

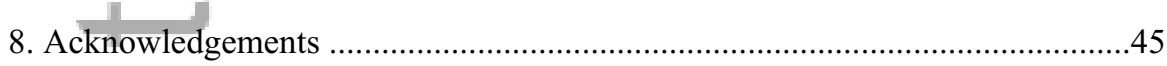

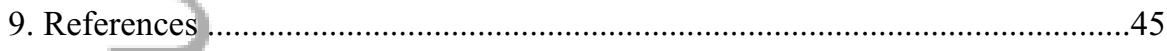




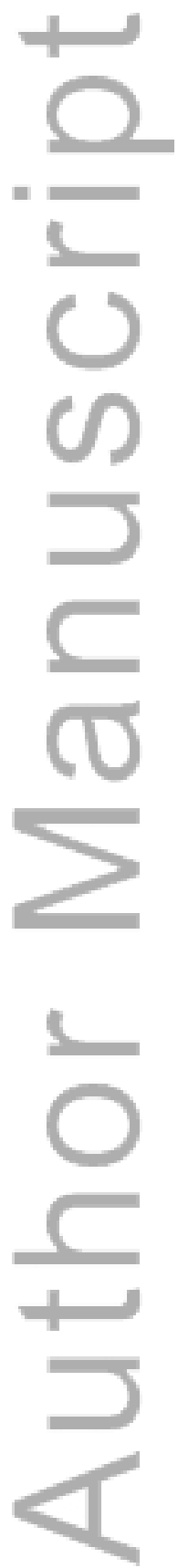

This article is protected by copyright. All rights reserved. 


\section{Introduction}

Over the past decades, extensive discussions about climate change have taken place around the world, analysing its potential implications for the way in which our society works, especially for the vulnerable populations in less developed regions. Within this discussion, there is a growing consensus that climate change is not just an issue of energy efficiency or industrial carbon emissions, as our approach to demanding development and economic growth has proven to be highly unsustainable in an ecological sense. ${ }^{1}$ Therefore, there is an urgent need to develop new and sustainable approaches to the manufacture and consumption of materials as a key component of the move to minimise waste generation. This also requires maximising the conversion of wastes into valuable resources. Figure 1 presents some concepts related to the (current and potential) implementation of closed-loop material flows in the construction industry, focusing specifically on urban and agricultural (rather than broader industrial) wastes, and the relationships between different industry sectors and waste generators of relevance in this context.Various wastes highlighted in Figure 1 (shaded in grey) are currently under-utilised or simply discarded, but offer potential for further valorisation through alkali-activation, and will form part of the focus of this review.

Across modern society, concrete is the second-most widely used material of any kind (after water), ${ }^{2}$ as it is the pillar of theinfrastructural developmentof our societyand the basis of a large fraction of the global built environment. Modern concrete is mainly composed of hydrated Portland cement (which acts as the binding phase in more than $98 \%$ of all concrete produced worldwide) along with natural sand and rocks, and the engineering properties of the concrete as a whole are largely controlled by the chemistry and design parameters of the binder. However, Portland cement is not the only type of binder which can be used in concrete. ${ }^{3}$ In the past decade, there has been rapid growth in international research efforts in the utilisation of wastes as alternative construction materials. One area of particularly rapid development has been the field of alkali-activatedor"geopolymer" cements, where the reaction between an alkali 
source (referred to as theactivator) and an aluminosilicate powder (referred to as theprecursor) yields a hardened binder with performance (and often also appearance) similar to that of Portland cement, ${ }^{4}$ but with a fraction of the $\mathrm{CO}_{2}$ emissions. ${ }^{5}$

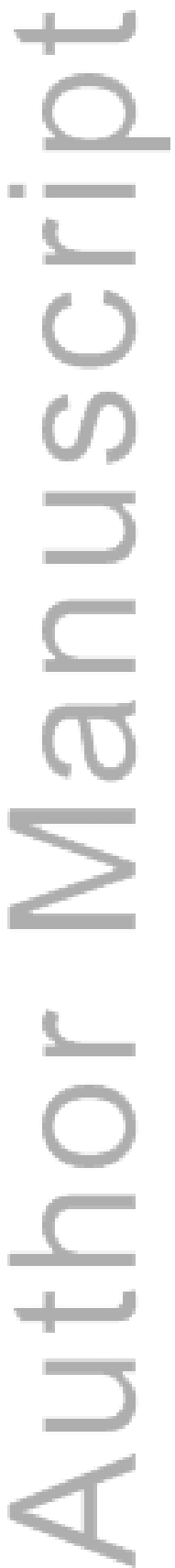




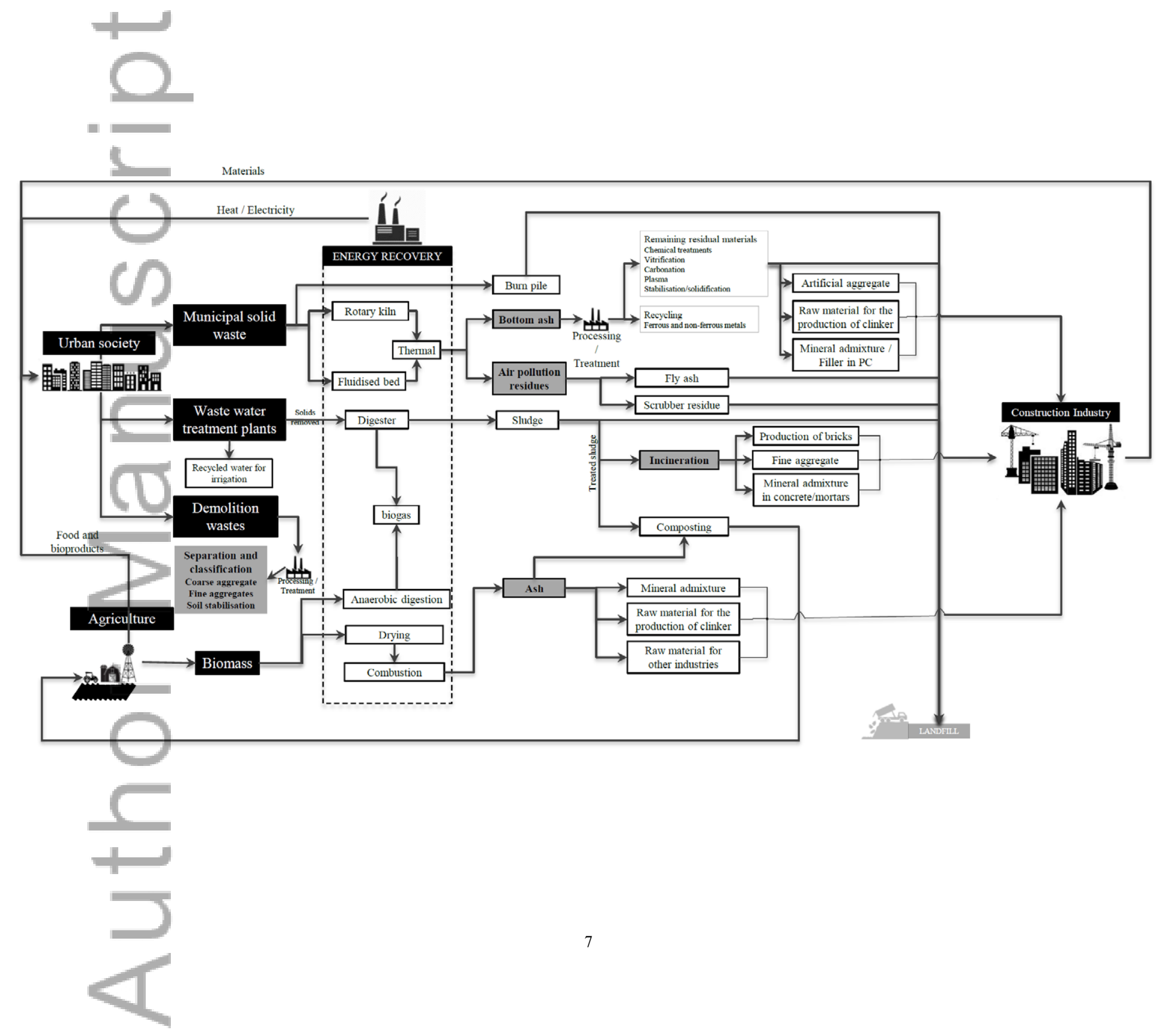

This article is protected by copyright. All rights reserved. 


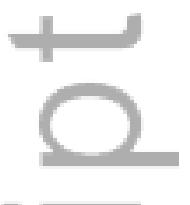

Figure 1. Schematic representation of some of the material flows related to recycling in the construction materials industry, focused on wastes generated directly by urban society and agriculture. Wastes identified in this review as having potential for use in alkali-activation are shaded in grey. 
Precursors which are generally used in research and in the current (relatively early) stages of commercialisation of alkali-activated cements include industrial by-products such as fly ash from coal combustion, and slags from iron-making processes; ${ }^{6}$ however, alkali activation can be applied to any material with a sufficiently high content of reactive $\mathrm{Al}_{2} \mathrm{O}_{3}$ and $\mathrm{SiO}_{2}$ species. In recent years, there has been significant growth in the use ofdifferent urban,industrial and mining wastes as precursors for production of alkali-activated materials, as the high existing demand forblast furnace slag and fly ash inblends with Portland cement represents one of the main barriersto the further deployment of alkali-activated cements on a large industrial scale. ${ }^{7}$ However, there does exist the need to increase the valorisation of some such wastes, especially for fly ash where the re-use rate can still be low:India, Middle East and Russiacurrently report fly ash utilisation ratesof $\sim 14 \%, \sim 11 \%$, and $\sim 19 \%$, respectively. ${ }^{8}$ There is also growing interest in the stabilisation/solidification of hazardous wastesvia alkali-activation, to reduce the severe environmental impacts which can be associated with their chemistry and toxicity. ${ }^{9,10}$

In this paper, we present an overview of some of the wastes that have been used as precursors for the production of alkali-activated materials, the main material properties obtained when using those wastes in alkali-activation, andthe associated development opportunities. Coal fly ashes and metallurgical slags will not be covered in detail, as their use in alkali-activation has been described in depth in recent reviews including. ${ }^{411}$ High quality coal fly ash and ground granulated blast furnace slag are also in high demand for blending in Portland-based cements and concretes, which brings an associated cost, and thus many of the likely opportunities for growth in lowcost alkali-activated material production may be identified as being linked to precursors which are not currently used in standardised Portland cement blends. ${ }^{12}$ The wastes to be discussed in detail here are outlined in Figure 2, which represents their approximate compositions on the $\mathrm{CaO}-\mathrm{SiO}_{2}-\mathrm{Al}_{2} \mathrm{O}_{3}$ ternary phase plane. Based on their chemical compositions, content of amorphous phases and degree of reactivity (which are all inter-related), the potential valorisation of these wastes through alkali activation can be addressed through two general alternative pathways: 
1. Use the waste as main precursor for the production of an alkali-activated binder for sale as a product in its own right, or

2. The use of alkali activation technology to develop a new outlet for a particular waste, including as an alternative source of $\mathrm{SiO}_{2}$ in the alkali activator, as a secondary precursor or blending agent, or even as an aggregate.
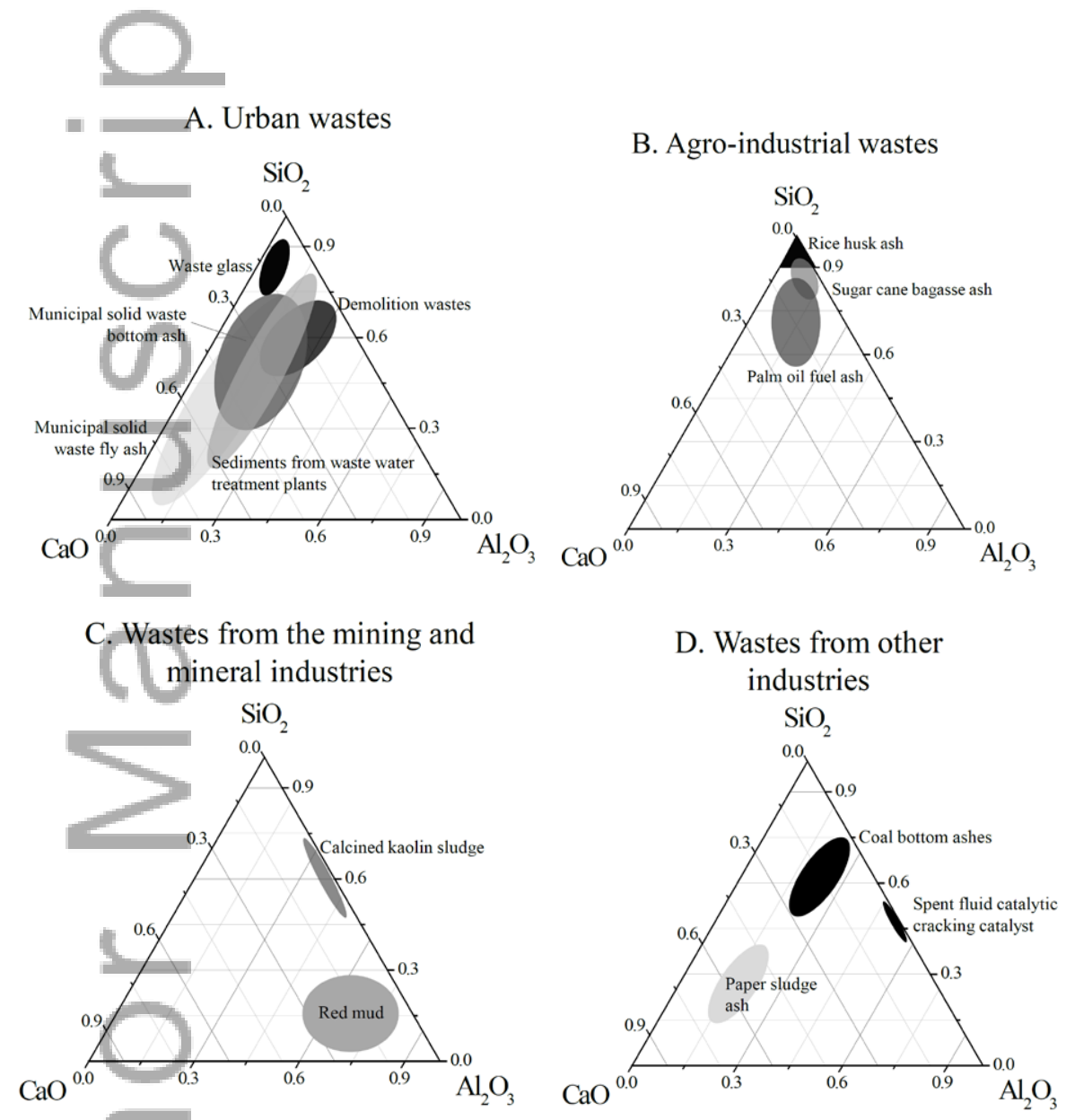

Figure 2. Approximate compositions of the wastes discussed in this review.

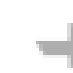

A key point thatis generally neglected in academic studies is the volume of material

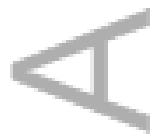


available in any particular location for the production of cements or concretes. Cement and concreteare generally produced in very large quantities (up to hundreds of thousands of tonnes per annum) from a specific production site, and so any process for their production based on wastes needs to have a long-term secure supply of the waste of at leâst tens of thousands of tonnes per annum. This also needs to be secured on a time horizon of multiple decades, to enable recovery of the capital cost of construction of the production facility and an economically viable degree of profitability. Academic studies based on a single waste source rarely consider such aspects of scale-up when promoting the use of a particular waste as a precursor for alkali-activated cements, and so this paper will aim to provide some insight where possible, regarding these issues.

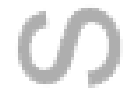

\section{Urban wastes}

\subsection{Ashes from municipal solid waste incineration}

The local and central authorities of urban and rural areas worldwide are currently under pressure to find responsible ways to manage and dispose of the municipal solid waste (MSW) that is produced every day. China alone generates over a quarter of total global MSW ( $\sim 250 \mathrm{Mt} / \mathrm{y})$, with a reported annualgrowth rate of 8 to $10 \%,{ }^{13}$ as a consequence ofits growing urbanisation and consumer-focused society. Landfill is the main strategy for MSW management in China, and only $\sim 15 \%$ of municipalwastes are incinerated. ${ }^{14}$ In the U.S.,the MSW that isrecyclable is less than $\sim 35 \%$ of total MSW arisings, ${ }^{15}$ and the non-recyclable wastes are landfilled, as this is an easy and currently inexpensive method for disposal.

Landfilling of MSW has severe environmental impacts including odour emissions, groundwater pollution from landfill leachate, and soil contamination. Therefore, the controlled incineration of municipal solid wastes (MSW) has become a more widespread way used to manage this kind of wastes. By direct incineration ofMSW, it is possible to reduce the volume of waste by converting it into an ash (achieving up to $80-90 \%$ volume reduction depending on the nature of the waste), and decrease the 
amount of waste that needs to be landfilled, ${ }^{16}$ with the added value that the energyrecovered from the heat that is released during the incineration of plastics, paper,other organic matter, and ferrous and non-ferrous metals can have significant financial value.

The main disadvantages associated with MSW incineration are the high levels of emissions of greenhouse and other problematic gases, and the large amounts of ashes which can be generated. ${ }^{17}$ These ashes can be categorised essentially intotwo groups: bottom ash (BA-MSW), which is the material that remains in the furnace after combustion, and the air pollution control residues that are removed from the flue gas. ${ }^{18}$ The BA-MSW represents $\sim 80 \%$ of the total residues generated during incineration ${ }^{19,20}$. Scrubber residues are retained by sorbents (such as lime or sodium hydroxide), and the fly ash (FA-MSW) is separated by filters or electrostatic precipitators $^{18}$, as shown inFigure 3.Figure 4 shows a scanning electron microscope (SEM) micrograph of a particle of FA-MSW, which depicts its heterogeneous, highly porousstructure and a particle size of around $50 \mu \mathrm{m}$.

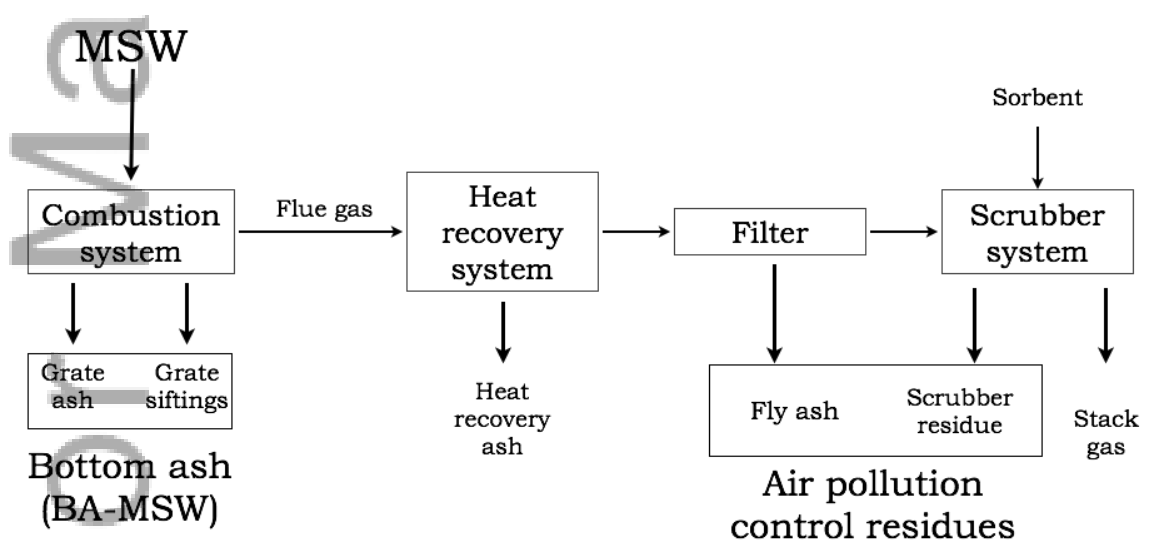

Figure 3. Basic unit operations and mass flows of an MSW incineration plant. ${ }^{18}$

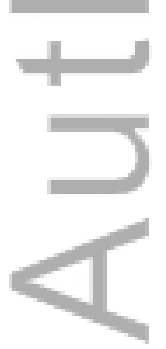




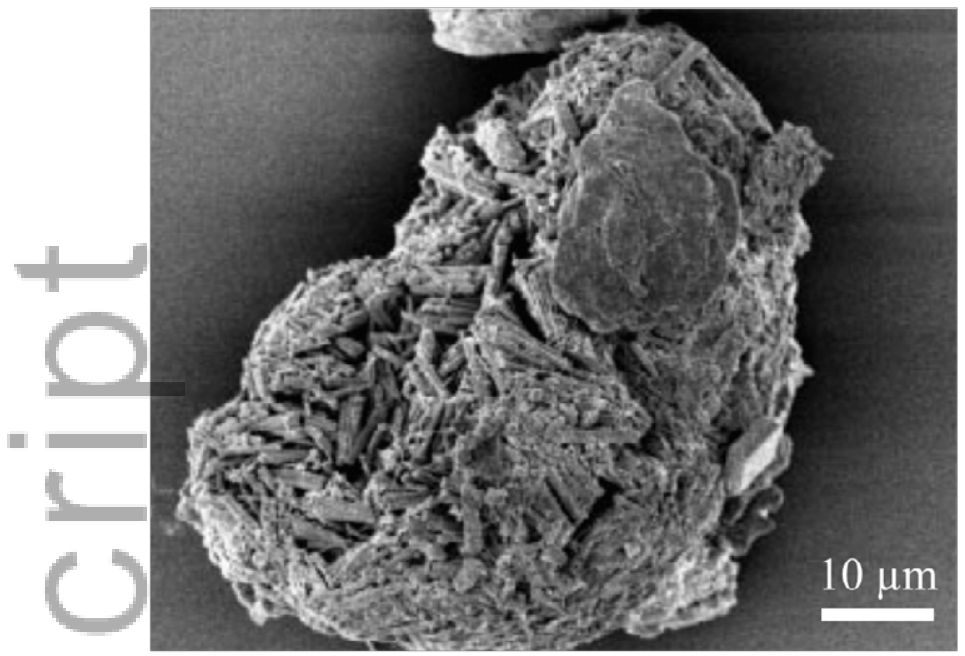

Figure 4. SEM image of a particle of FA-MSW showing the heterogeneous nature of this waste even within a single particle, and the intraparticle porosity. From Kersch et $a l^{21}$, copyright John Wiley \& Sons.

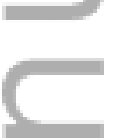

MSW ashes are often classified as hazardous due to the presence of toxic elements and organic compounds, andconsequentlythese ashes must be treated and disposed with care, consideringregulatory aspects and specifications such as the European Waste Catalogue List (19 01). ${ }^{22}$ The major elements present in MSWashes are mainly $\mathrm{O}, \mathrm{Si}, \mathrm{Ca}, \mathrm{Al}, \mathrm{Fe}, \mathrm{Na}$, and K. BA-MSW also has carbon due to unburned material. Although most of the metals are present as oxides, there are also considerable quantities of metal chlorides, metal sulfates and metal carbonates, and some nonoxidised metallic components. Some ashes may also contain significant amounts of polycyclic aromatic hydrocarbons (PAH), polychlorinated biphenyls (PCB), chlorobenzenes, chlorophenols, chlorinated compounds, benzofurans or mutagenic organic chemicals. ${ }^{23}$ When the MSW ashes are used by the construction industry or asgeotechnical materials, the leachability of these organics, as well as alkalis and heavy metals, is a major concern, as these can affect the properties of the concretes and the soils. Ashes with high chloride content are alsoseverelyrestricted from usage

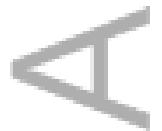


in reinforced concretes due to the risk of corrosion of the embedded steel reinforcement.

Currently, the utilisation of ashes from MSW combustionis very limited, especially if the ash has not been pre-treated, and also due to the intrinsically high variability of this type of ash. Some ashes are decontaminated by different processes, including wet chemical treatment, ${ }^{24}$ thermal or plasma vitrification, ${ }^{25,26}$ carbonation, ${ }^{27}$ or disposed via stabilisation/solidification $(\mathrm{S} / \mathrm{S})$ in a cementitious matrix. ${ }^{18}$ Life cycle analysis hasenabled quantification of the environmental benefits associated with the re-use, particularly metal recovery, of the MSW ashes; a significant reduction is observed related to the global warming impacts. ${ }^{28}$

The recycling of MSW ashes by the construction industry has increased worldwide over the past years, including the assessment and use of FA-MSW and BA-MSW as aggregates, ${ }^{29-32}$ as raw materials for Portland clinker production, ${ }^{33,34}$ and as mineral admixtures for the production of concretes. ${ }^{35}$ Some studies have identifiedthat the presence of slowly-reacting siliceous glass or metallic aluminiumparticles in the ashes derived from MSW might negatively affect the durability properties of cements and concretes, as these components can increase the susceptibility to degradation, viathe alkali-silica reaction or the release of hydrogen gas, respectively. ${ }^{29,36}$

The stabilization/solidification (S/S) of MSW ashes via alkali-activation has also been assessed. The mechanisms of heavy metal immobilisation in an alkali-activated binder can be physical and/or chemical, where the hazardous elements are either fixed in the gel network, linked into the structure in change balancing roles, or physically trapped in a dense and low-permeability matrix. ${ }^{37}$ Luna-Galeano et al. ${ }^{38}$ studied FA-MSW incorporation into alkali-activated systems based on a variety of precursors (including metakaolin, blast furnace slag and coal combustion fly ash) and alkali activators (sodium and potassium hydroxide and silicate). Although the mechanical performance of the wasteforms produced was relatively low ( $<10 \mathrm{MPa}$ after 28 days), the leachability of Zn, Co, Ni and Sn was greatly reduced compared to the raw MSW ash. 
Lancelloti et al. $^{39}$ showed that metakaolin-based systems can stabilise larger amounts of MSW ashes when compared with conventional cementitious S/S.

The use of untreated MSW ash as a precursor in the production of alkali-activated binders is limited due to its toxicity and the low contents of amorphous, reactive $\mathrm{SiO}_{2}$ and $\mathrm{Al}_{2} \mathrm{O}_{3}$-containing phases. However, some MSW residues have been shown to be suitable to be used in this way ${ }^{40,41}$; Zheng et al. ${ }^{41}$ achieved compressive strengthsof up to $20 \mathrm{MPa}$ after 7 days of curing for such materials. The use of $\mathrm{CaO}$ for flue gas treatment in MSW incineration facilities generates fly ashes rich in Ca-compounds $\left(\mathrm{Ca}(\mathrm{OH})_{2}, \mathrm{CaCO}_{3} \text {, or } \mathrm{CaSO}_{4}\right)^{42}$, and these can be beneficial for strength development and permeability reduction in alkali-activated binders. Some FA-MSW materials can be treated by washing to reduce the content of undesirable elements such as $\mathrm{Cl}, \mathrm{Zn}$, $\mathrm{Cu}, \mathrm{Cr}, \mathrm{Pb}, \mathrm{Cd}$ and $\mathrm{Ni}$. Zheng et al. ${ }^{40}$ also reported that after a washing treatment, an FA-MSW exhibited higher reactivity in alkali-activation, yielding a binder with improved mechanical performance due to the removalof the chloride which was affecting setting and mechanical performance. ${ }^{43,44}$ This was consistent with the results of Ferone $\mathrm{et} \mathrm{al} .{ }^{45}$, who evaluated the effect of blending fly ash with FA-MSW which had been pre-washed to remove both chloride and sulfate, and found an improvement in terms of leaching performance. However, the washing process does itself generate a secondary liquid waste stream which requires further treatment, and this added cost must be considered when assessing the desirability of the washing step in waste treatment.

Diaz-Loya et al. ${ }^{46}$ assessed alkali-activated systems based on blends of coal FA and FA-MSW. Their materials based solely on FA-MSW showed leachability of heavy metals (with the exception of Se) which was withinthe allowable limits according to the US Environment Protection Agency.The alkali-activated binderscontaining 60\% FA-MSW exhibited mechanical performance which was suitable for the production of non-structural precast products: a compressive strength of $18 \mathrm{MPa}$ and flexural strength of $2.8 \mathrm{MPa}$ after curing at $100^{\circ} \mathrm{C}$ for 7 .

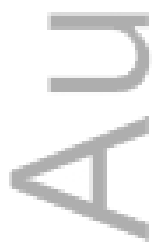


In general, unless a decontamination treatment is applied, the use of MSW ashes as a raw material for alkali-activated cements in civilconstruction applications seems limited, as the products may not comply with the toxicity regulations to be used as a building material, and will tend to be variable in quality and performance. In this sense, MSW ashes present challenges related to valorisationas a construction material via alkali-activation, and future work in this area is likely to be driven predominantly by environmental arguments and the need to avoid landfilling of the waste ash, rather than =any particularly desirable or unique technical properties of the materials produced. However, it does seem that solidification/stabilisation using alkali-activated matrices may be a viable route for themanagement of this waste via incorporation into a solid binder rather than simply landfilling it, as such a process cancontribute significantly to reducing the leachability of toxic elements to the environment.

\subsection{Demolition and ceramic-type wastes:}

Roughly $45 \%$ of the total wastes arising from construction processes are ceramic-type wastes $^{47}$, which are produced from two mainsources:

- Wastes generated by demolition and construction activities: including construction and demolition wastes: concrete, bricks, roof tiles and ceramic materials.

- Wastes generated by the ceramic industry: including waste from thermal processes or from the manufacture of bricks, roof tiles and construction materials.

These wastes are generally classified as non-hazardous, ${ }^{22}$ as long as no asbestos is present. According to Dahlbo et al., ${ }^{48}$ the current construction and demolition waste management system of the European Union needs to be significantly updated and modified in order to achieve the target of recycling a minimum of $70 \%$ in 2020 as suggested by the EU Waste Framework Directive (2008/98/EC). However, the main problems in the utilisation of wastes generated by demolition and construction materials are related to the lack of control of composition (which is very 
heterogeneous) and thedifficulty in extracting certain contaminants, e.g. wood, paper, gypsum, glass, rubber, among others. ${ }^{49}$ Europe and the U.S. have made significant advances over the past decades inthe correct classification and subsequent reuse of construction wastes. New techniques to ensure effective separation, instead of selective demolition and manual sorting, are nowutilised,such as wet jigging, ${ }^{50}$ air jigging, ${ }^{49}$ heavy liquid separation, ${ }^{51}$ optical sorting and near-infrared sorting technology 52 .

The main consumer of these wastes is the same construction industry which generates them, and common applications include soil stabilisation, use as a fill material for landscaping, asan artificial aggregate in the production of concrete, and/or use as a raw material for the production of Portland cement. ${ }^{53-56}$ However, in growingeconomies where high volumes of ceramic and demolition wastes are generated, the potential for recycling and re-use of these wastes is often not reached as a consequence of thelow cost and high volume availability of virgin raw materials, as well asthe limited expertise available for treating wastes and thelimited allocation of resources for waste management. Recently, life cycle analysis modelling has demonstrated that the re-use and valorisation of construction and demolition wastes can reduce the footprint of the industry across mostenvironmental impact categories. ${ }^{57,58}$ However, transportation is the most important impact to be considered; its contribution to the global warming impacts can be high, and may in fact dominate other benefits if local valorisation is not possible. ${ }^{58}$

The use of demolition wastes for the production or development of alkali-activated cementsis challenging, considering the varying nature of these wastesandthe consequent lack ofconsistency in chemical and physical properties across wastes from different sources.There is also a high energy and financial cost associated with the reduction of wastes to a sufficiently fine particle size for use as a precursor in alkaliactivation, as crushing to a particle size in the range of tens of microns is very much more expensive than when targeting a normal aggregate particle size (a few

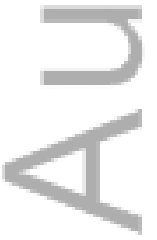


millimetres to a few centimetres), and problematic dust emissions may also be associated with this process.

However, there do exist reports related to the use of demolition wastes as aprecursor for production of alkali-activated cements. For example, Payá et al. ${ }^{59}$ assessed hydrated Portland cement which had previously been carbonatedin an attempt to replicate end-of-life conditions for cement in regular concretes,byalkali-activation with $\mathrm{NaOH}$ and waterglass. Their mortar specimens cured at $65{ }^{\circ} \mathrm{C}$ after 3 days exhibited a compressive strength on the order of $10 \mathrm{MPa}$, demonstrating potential use of cement-rich fraction of the demolition wastes, which isnot strongly desirableas an aggregate due to its high water demand in concrete mixtures.The applicability of cement recovered from demolition wastes as a precursor for alkali-activated materials is likely to belimited by competition from the re-use of this material in Portland cement clinker manufacture, and so further assessment will be required to elucidate thetrue feasibility of this option from financial, technical and environmental points of view.Recently, Komnitsas et al. ${ }^{60}$ demonstrated the potential use of constructionand demolition wastes (including recycled concrete, bricks and tiles) as raw materials for the synthesis of geopolymers:high mechanical strength $(>40 \mathrm{MPa}$ after 7 days of curing) was achieved under specific synthesis conditionsusing wastes derived from tiles and bricks. However, the demolition wastes based on recycledconcrete (regardless of the particle size distribution) showed a lower degree of reactivity and lower mechanical performance. These results elucidate the importance of developing an effective selection and screening process for the demolition wastes prior to use as a precursor in alkali-activation, taking into account their heterogeneity.

Therefore, the wastes generated by the ceramic industry can probably bereused more easily than general demolition wastes due to thegreater control of composition, and thusreduced variability. The largest producers of clay-basedceramic tiles are China, Brazil, India, Italy, Iran and Spain, which together represent $\sim 70 \%$ of global production, ${ }^{61}$ and in these countries, the residues generated during the production of ceramic products are mainly disposed in landfill. These ceramic wastes consist mainly 
ofsilicate and aluminosilicate minerals obtained through the calcination of clays, such as quartz $\left(\mathrm{SiO}_{2}\right)$, feldspars $\left(\mathrm{MAlSi}_{3} \mathrm{O}_{8}\right.$ where $\mathrm{M}$ is an alkali metal) and vitreous phases. Several studies have described ${ }^{62,63}$ the use of these ceramic wastes as a coarse or fine aggregate for concrete or mortar production, or asa raw material for the production of Portland clinker. ${ }^{64,65}$

Some ceramic wastes doshow pozzolanic reactivity, as they contain amorphous aluminosilicate phases which react with the portlandite formed during the hydration of Portland cement. ${ }^{66-69}$ Although the pozzolanicity of thesewastes is significantly lower than that of other calcined clays (such as metakaolin), theirvalueas precursors in alkali-activated cement production can be optimised through control of the formulations and the activation conditions. Reig et al. ${ }^{47,70}$ evaluated the alkaliactivation of an aluminosilicate wasteobtained from red clay bricksand porcelain stoneware; mortars cured at $65^{\circ} \mathrm{C}$ for 7 days developed compressive strengths exceeding $20 \mathrm{MPa}$, demonstrating that it might be feasible to reutilise these wastes for the production of alkali-activated cements. Allahverdi and Najafi Kani ${ }^{71}$ produced alkali-activated pastes based on blends of waste bricks and 8-month old crushed concrete, which achieved compressive strengths of up to $40 \mathrm{MPa}$ after 28 days of curing.

The use of recycled crushed material obtained from bricks and other clay products as raw materials for the development of alkali-activated cements is currently quite limited, although studies including thosedescribed above suggest that it maybe technically achievable. One of the main limitations in a practical sense is the low volume of production of clay-based demolition waste in any particular location,compared with what might be commercially required for production of alkali-activated cements at an industrial scale, as most activities which generate such wastes are small in scale. Likewise, the growing demand for low-cost housing in manyareas around the world has led to the development of improvised brick factories, whose product control is minimal, which can consequently affect the potential reactive quality of the powdered brick after recycling. 
Conversely,ceramic wastes such as broken or off-specification porcelain stoneware, tiles, tableware and others, that can be sourced directly from the factories manufacturing these products rather than from the demolition process, could have higher potential as precursors for alkali-activated cements, as the raw materials and process of mannufacture are well known, and therewill be greater consistency in the properties of the wastes to enableoptimisation of alkali-activated cement formulations. This is an interesting area of research that needs to be further explored, although the volumes of these wastes available from each single source tend to be rather small compared to the scale of cement production facility throughput values, and so such products may be best utilised in niche products such as refractories, ${ }^{72}$ which can make use of their intrinsically high thermal resistance, rather than in production of bulk construction materials.

\subsection{Wastes or sediments from water treatment plants}

Sewage sludge is a residue generated by the wastewater treatment process, where the liquid and solids fractions are separated. Residues are collected during the primary (physical and/or chemical), secondary (biological) and tertiary (nutrient removal) treatment. The solids collected can be subjected to further treatments (including biological, thermal, long-term storage, among others) and are finally disposed.The quality of the sludge produced isaffected by the degree of pollution of the effluent treatedand the technical features of the water treatment plant. The physical and chemical processes involved in sewage sludge treatment tend to increase the concentrationsof heavy metals, such as $\mathrm{Zn}, \mathrm{Cu}, \mathrm{Ni}, \mathrm{Cd}, \mathrm{Pb}, \mathrm{Hg}$ and $\mathrm{Cr}^{73}$ as water is progressively removed from the sludge. In Europe, $35-45 \%$ of the sewage sludge generated is still landfilled, $37 \%$ is used in agriculture, $11 \%$ incinerated and the remainder is used in other areas such as forestry and land reclamation. ${ }^{74}$ The presence of hazardous compounds restricts the use of sewage sludge in agriculture due to its potential ecotoxicity, and therefore it has to be assessed carefully before utilisation, to reduce any harmful effects. ${ }^{75}$ 
There exist some reports related to the co-combustion of sewage sludge in cement manufacturing, where the calorific power of the organic fraction of the sludge is used as a source of energy. The main restriction inblending the sludge with coal for combustion within the kiln is the emission of harmful elements,including heavy metals which can accumulate in the cement kiln dust. On other hand, the ashes generated during the incineration of sludge wastes have been used in the construction industry as a fine aggregate, as a mineral admixture in concrete/mortars mixes, ${ }^{76}$ or as a raw material for the production of bricks. ${ }^{77,78}$ There do not exist reports related to the assessment of sewage sludge ashes as the sole raw material in the production of alkali-activated cements, as these ashes tend not to contain high contents of reactive aluminosilicates;instead, alkali-activated cements have been examined as potential solidification/stabilisation matrices for these ashes, to reduce the leachability of heavy metals.

Yamaguchi and Ikeda ${ }^{79}$ evaluated the solidification of sewage sludge slag, which is produced via the melting of the sludge at high temperature, in a fly ash based geopolymer matrix. It was identifiedthat the sewage sludge slag was an 'active filler' and the best mechanical strength was obtained ata 25 wt.\% sludge slag loading, although high temperature curing $\left(80^{\circ} \mathrm{C}\right)$ was required to produce monoliths.Suchslags could potentially be utilised in the production of alkali-activated matrices, but further research in this area would certainly be required, especially regarding immobilisation of heavy metals.

Reservoir sludge is a by-product resulting from the storage and treatment of potable water, mainly consisting of deposited clays and silt, and thus contains much lower levels of toxic substances than sewage sludge. It can therefore be categorised in most cases as a non-hazardous waste and may be reused in different engineering applications. Taking into account itsrelatively high content of clay minerals, reservoir sludge can be thermally treated to produce bricks or lightweight aggregates, ${ }^{80}$ or blended with other precursor materials as a reactive component of an alkali-activated binder system. It has been demonstrated ${ }^{81}$ that the compressive strength ofternary 
alkali-activated binders with30 wt.\% blast furnaceslag, $20 \mathrm{wt} \%$ metakaolin and 50 wt.\% calcined reservoir sludge increases significantly when the sludge is thermally treated at800-850 ${ }^{\circ} \mathrm{C}$, consistent with the thermal activation of the clay minerals present. The maximum compressive strength reported was 56 MPaafter 28 days of curing, and the mechanical performance was reduced slightly when the content of the calcined reservoir sludge was increased. Foamed alkali-activated panels based on calcined reservoir sludge with $30 \%$ blast furnace slag have also been shown to generate valuable sound-insulation properties, as expected for a low-density material based on calcined clays, offering an alternative to the use of more expensive commercialmetakaolin sources in such applications. ${ }^{82}$

The use of calcined reservoir sludge as the sole aluminosilicate component of an alkali-activated binder was evaluated by Ferone et al., ${ }^{83,84}$ using $\mathrm{NaOH}$ and waterglass solutions as alkali activators.The sediments werebased on quartz, feldspar, kaolinite, illite and smectite, and after being thermally treated at up to $750{ }^{\circ} \mathrm{C}$ and combined with the alkali activator, the materials developedcompressive strengths lower than 12 MPa after 3 days at $60{ }^{\circ} \mathrm{C}$. Strength development was improved greatly (38 MPa under the same conditions) when some blast furnace slag was added as a more reactive secondary constituent of the binders.

Alkali-activationseems to be a suitable technology for exploiting reservoir clay sediments, which do not currently have commercial value. It is important to note that the variation in clay content and nature means that mix design optimisation (including blending with other aluminosilicate materials) will be needed in each location rather than using a single universal 'ideal' formulation. However, alkali-activation technology seems to be a suitable alternative for the manufacture of valuable products from these wastes.

\subsection{Waste glass}

The rates of production and consumption of glass for packing differ widely between countries, and so in some countries a very high degree of reuse or recycling of waste

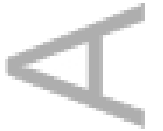


glass is achieved, while in others (particularly countries which are high-volume importers of wine), there are a lot of waste glass bottles generated which are not suitable for domestic re-use. In EU, the glass packing waste generated was $32 \mathrm{~kg}$ per capita in 2011. Although the 2008target of 55\% waste glass (WG) recycling has been achieved by most EU Member States, there still existsscope to increase the recycling and recovery rate. ${ }^{85}$ The non-recyclable mixed-colour broken glass from used bottles,along with the glass from fluorescent lamps,can represent an environmental problem for municipal waste treatment plants as the glass is not biodegradable, and landfilling is not making effective environmental or economic use of the value and energy embodied in these residues. According to Vossberg et al.X, glass recycling shows significant energy savings $(>25 \%)$ and greenhouse gas emissions reduction ( $35 \%)$ when compared to landfilling. ${ }^{57}$

The efficiency of the glass recycling process is strongly affected by the collection method and the ability tosort the glass by colour. If glasses of different colours are correctly separated, they can be used many times without significant changes in chemical or optical properties. However, when coloured glasses are mixed, they are not suitable for reuse and then are disposed mainly in landfills. Additionally, although used fluorescent lamps are typically processed to remove the mercury and reduce itsconcentration to thelevels recommended by the Waste Acceptance Criteria $(<0.2$ $\mathrm{mg} / \mathrm{kg}){ }^{86}$ the growing adoption of fluorescent lighting systems is making difficult the safe disposal and recycling of the full range of lamps available on the worldwide market.

The use of waste glass in Portland cement production has generally been avoided, as it increases the alkali content in the clinker, which can generate alkali-aggregate reactions as well as the potential for flash setting due to the formation of highly soluble sulfate salts. ${ }^{87}$ The use of waste glass as a partial replacement of coarse or fine aggregate in the production of concrete is also limited, again due to the reaction induced between the reactive silica present in the glass and the alkalis of the Portland cement (and the glass itself). However, when the waste glass is crushed and 
pulverized to smaller than $300 \mu \mathrm{m}$, andaluminous supplementary cementitious materialssuch as coal fly ashare used,the deleterious effect attributed to the alkalisilica reaction decreases. ${ }^{88,89}$ Somevery finely ground waste glasses show pozzolanic activity, and theycan be used for the partial replacement of Portland cement for concrete production, as they may enhance mechanical performance. ${ }^{90}$

In the context of alkali-activation of waste glasses, two main approaches have been investigated: use of the waste glass as a solid precursor for the alkali-activated cement, or as a raw materialfor the production of low cost sodium silicate solutions.In utilising waste glass as a precursor for alkali-activated cement production, Cyr et al. ${ }^{91}$ assessed the use of a green soda-lime-silica waste glass activated by alkali hydroxide solutions, and obtained mortars with a compressive strength of up to $\sim 60 \mathrm{MPa}$ after 56 days of curing. As the content of $\mathrm{SiO}_{2}$ in the waste glass was quite high $(\sim 72 \%)$, the use of a silicate activator was not necessary to achieve high compressive strengths. The absence of a sodium silicate-based activator significantly reduces the cost of production of these materials.

Redden et al. ${ }^{92}$ carried out a comparative study activating glass powder, fly ash, and blends of these materials, and identified that the glass powder-based activated cements developed higher strengths than activated fly ash cements when cured at room temperature. However, the main reaction product of glass activation was a sodium silicate gel, which was highly soluble in water and alkaline media, calling into question the stability of these cements in a real service environment in the absence of an added aluminium or calcium source thatcould generate an insoluble gel. AvilaLópez et al. ${ }^{93}$ utilised urban waste glass, blended with limestone as a low-cost source of calcium,to produce alkali-activated cements. Higher reactivity of the waste glass was identified when using $\mathrm{NaOH}$ as an activator, which promoted the formation of a $\mathrm{C}-\mathrm{S}-\mathrm{H}$ type gel along with the hydrous $\mathrm{Ca}-\mathrm{Na}$ carbonate salt pirssonite as main reaction products. Compressive strengths of up to $38 \mathrm{MPa}$ were obtained in optimised mixes.

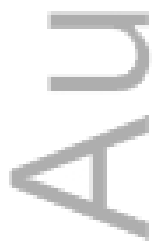


Badanoiu et al. ${ }^{94}$ synthesised foamed alkali-activated cements using waste glass cullet, red mud, and blends of these materials, activated by solutions of $\mathrm{NaOH}$ and liquor derived from the filtration of red mud slurry, with the aim of using wastederived materials as both precursors and activators. These foamed cements developed a compressive strength of $25 \mathrm{MPa}$ after curing at $60^{\circ} \mathrm{C}$ for $24 \mathrm{~h}$ then at $20^{\circ} \mathrm{C}$ and $85 \%$ relative humidity (RH) for 7 days.

These studiesdemonstrate that waste glasses can certainly be used as precursors for producing hardened alkali-activated cementitious materials. However, the mix designs need to be adjusted and optimised in order to produce stable reaction products, so that these cements can withstand service conditions, and therefore develop desirable durability.

Puertas and Torres-Carrasco have also demonstrated theproduction of sodium silicate solutions via chemical digestion in $\mathrm{NaOH} / \mathrm{Na}_{2} \mathrm{CO}_{3}$ solutions of urban waste glasses, ${ }^{95}$ and have used these solutions as alkali activator for producing cements based on alkali-activated slag, ${ }^{96}$ and alkali-activated fly ash. ${ }^{97}$ These studies have elucidated that waste glass can be recycled for production of sodium silicate solutions, and that these solutions can act as effective activators for producing alkali-activated cements, as similar compressive strengths and phase assemblages were identified when using these alternative activators compared with those obtained when using commercial sodium silicates. This seems to be a very viable alternative for the recycling of waste glass to produce a valuable product.

Other types of waste glass, such as solar panel residue glass, ${ }^{98}$ havealso been utilisedin laboratory studies as a partial replacement material in metakaolin-based activated cements. Although material performance seemed acceptable on a lab scale, the applicability of such processes (or those including post-consumer glasses from electronic items such as display screen equipment) atan industrial scale is likely to be infeasible, considering the lowvolume availability ofsuch residues worldwide or in any particular location; a very large (and expensive) number of broken panels or screens would be required to produce a useful quantity of concrete. However, as 
hazardous elements might be present in the waste glass, alkali-activation technology could be a suitable alternative for its safe disposal if the production of a monolithic wasteform is desired.

\section{Agro-industrial wastes}

\subsection{Rice husk ash}

Rice is a cereal grain, and is the most widely consumed staple food for a large part of the world. It is the third-highest produced crop worldwide (744 million tonnes in $2014^{99}$ ), after sugarcane and maize. ${ }^{100}$ Every five tons of rice from paddy cultivation produce one ton of rice husk waste, and in 2014 alone more than 148 million tonnes of rice husk were produced worldwide. Currently, some rice husksareutilised as fuel, and the resulting ashes, Figure 5, are a low cost source of amorphous silica that has been extensively used by the construction industry as a supplementary cementitious material for concrete production. ${ }^{101,102}$ The pozzolanic activity of a rice husk ash depends on itscontent of amorphous silica and unburnt carbon, the particle size distribution and specific surface area, all of which are strongly affected by the combustion temperature and duration. ${ }^{101,103}$

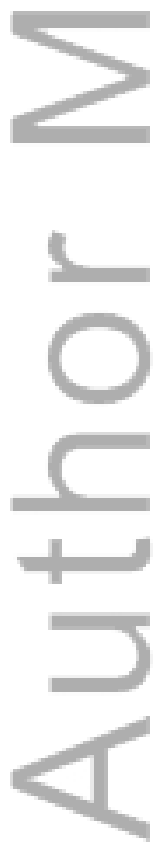




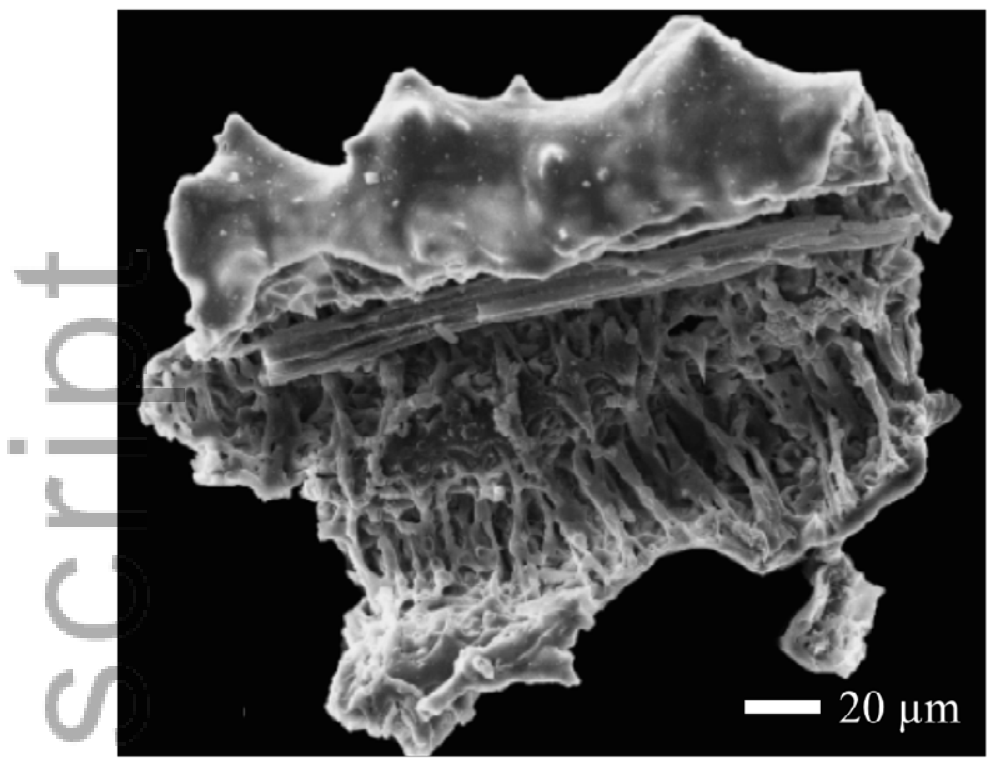

Figure 5. SEM micrograph of a rice husk ash particle, showing its porous structure which yields a high specific surface area and thus rapid reaction. From Abreu et al., ${ }^{104}$

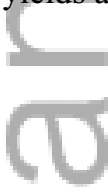

In the context of alkali-activated cements, similar to the situation discussed in the preceding section for waste glasses, rice husk ash has been used both as a secondary precursorand as a silicate source for production of sodium silicate activating solutions.

Detphan et al. ${ }^{105}$ used rice husk ash, produced at different combustion temperatures, as partial replacement material in alkali-activated coal fly ash cements. The rice husk ash fineness and the degree of fly ash replacement strongly influenced the compressive strength; mechanical strengths of up to $56 \mathrm{MPa}$ were achieved when the rice husk ash was sintered at $690^{\circ} \mathrm{C}$ and the amount of small particles increased. Rattanasak et $a l .{ }^{106}$ blended rice husk ash with $\mathrm{Al}(\mathrm{OH})_{3}$ to produce alkali-activated cements, adding sodium hydroxide and sodium silicate as alkali activators. Boric acid was also added 
to these binders to reduce their solubility in water. The formation of an aluminosilicate type gel as the main reaction product in these binders was observed,withcompressive strengths between 14 and $20 \mathrm{MPa}$ after 90 days of curing, depending on the $\mathrm{Al}(\mathrm{OH})_{3}$ content. This study elucidated that hardened solids containing more than $70 \mathrm{wt} . \%$ rice husk ash can be produced, and that these materials can achieve moderate but useful compressive strengths.

He et al. ${ }^{107}$ assessed the compressive strength and microstructural features of red $\mathrm{mud} / \mathrm{rice}$ husk ash blended alkali-activated cements, and identified that an increased content of red mud promoted the development of higher compressive strengths, depending on the formulation of the binders. As observed by Rattanasak et al. ${ }^{106}$, an aluminosilicate type gel is forming in these cements, which is responsible for mechanical strength development over the time of curing.

Gastaldini et al. ${ }^{108}$ produced blended concretes containing $80 \mathrm{wt} . \%$ Portland cement, 20 wt. $\%$ rice husk ash, and 1 wt. $\%$ of either $\mathrm{Na}_{2} \mathrm{SO}_{4}, \mathrm{~K}_{2} \mathrm{SO}_{4}$ or $\mathrm{Na}_{2} \mathrm{SiO}_{3}$. An increase in the compressive strength development at early time of curing (7 days) was identified when alkali activators were included, along with a significant reduction in chloride permeability of the concretes.

The dissolution of rice husk ash into concentrated $\mathrm{NaOH}$ to produce sodium silicate solution as an alkali-activator is an attractive application of this waste in the field of alkali-activation technology.Bernal et al. ${ }^{109}$ evaluated the effectiveness of this alternative activator in producing cements based on slag, metakaolin and their blends. This study elucidated that the mechanical performance and structural development of the alkali-activated cements produced with the waste-derived activator was comparable with the results obtained when using a commercial sodium silicate solution ofcorrespondingchemical composition. Similar observations have been identified when using these alternative activators in producing alkali-activated cements based on coal fly ash/slag blends ${ }^{110}$ or spent fluid catalytic cracking catalysts. ${ }^{11}$

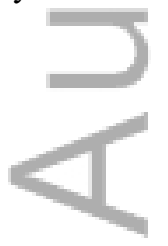


The thermal resistance of alkali-activated slag cements produced with a rice-husk ash based activator has also been assessed, ${ }^{112}$ with higher retention of compressive strength after treatment at up to $1000^{\circ} \mathrm{C}$ than in comparable cements produced with a commercial silicate solution. Villaquirán-Caicedoet al. ${ }^{113}$ observed the formation of different crystallisation products upon high temperature exposure of alkali-activated metakaolin binders based on waste-derived or commercial sodium silicate activators, which could influence the performance of these binders under fire conditions.This was associated with the differences in the speciation of the soluble silicates available during the activation reaction when using rice husk ash based or commercial sodium silicate solutions.

\subsection{Palm oil fuel ash}

Palm oil is now a significant bio-based energy source in many parts of the world, particularly in Southeast Asia, Africa and South America. The main wastes derived from the palm oil production process are shells, palm kernel cake and fibres, among others, which are often utilised as fuel for steam production in palm oil mills. During this combustion process, a large quantity of siliceous ashis produced, and over the past decadesthis has begun to be utilised as apartial pozzolanic replacement for Portland cement in producing concrete. ${ }^{114-116} \mathrm{As}$ in the case of other biomass ashes, the palm oil fuel ash particles exhibit heterogeneous shape, a cellular structure and high specific surface are (Figure 6), which increase water demand when used as a mineral admixture in cements and concretes. ${ }^{116}$ Recentefforts have also focused on maximising the recycling of palm oil fuel ashes via alkali-activation, as there isa rapidgrowthin palm oil production, and interest in biomass combustion to produce electricity as a means of reducing the cost of disposal of these wastes. 


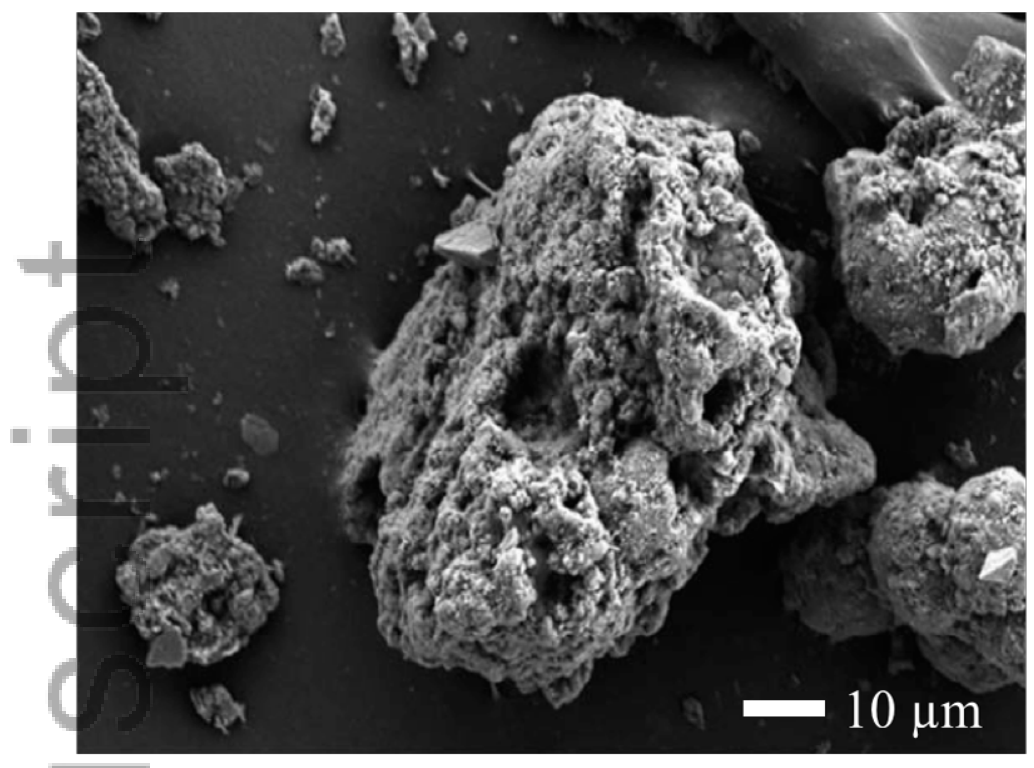

Figure 6. SEM image of a particle of palm oil fuel ash, showing the porous structure of the larger particles present. FromOoi et al., ${ }^{117}$ copyright John Wiley \& Sons.<smiles>C1CCC1</smiles>

Most of these studies have been based on a single source of palm oil by-product ash, and have focused on the assessment of the effects of different mix design parameters on the strength development and basic microstructural features of alkali-activated cements based on palm oil fuel ash. However, this approach has meant that there is little broader generic information available regarding this class of ashes as a whole, as each study considers only the characteristics of a single material. There is a high degree of variability between palm oil fuel ashes in terms of composition and mineralogy, although most tend to be relatively low in reactive alumina content and thus challenging to use as a sole precursor for alkali-activated cements. Salih et $a l .{ }^{118}$ assessed the effect of the curing temperature and duration on the compressive strength development of these cements, identifying that comparable compressive strengths (21-24MPa after 7 days) were obtained in samples cured at room temperature compared with specimens cured at between $60^{\circ} \mathrm{C}$ and $80^{\circ} \mathrm{C}$. This

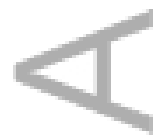


elucidated that high temperature curing is not required for these cements, if the mixes are appropriately designed.

The utilisation of palm oil fuel ash as a secondary precursor for production of blended alkali-activated cements has also been widely studied, andthe fineness of these ashes has a strong influence on reactivity and consequently strength development. Yusuf $e t$ $a l$. produced alkali-activated cements ${ }^{119}$ and concretes ${ }^{120}$ based on blends of ultrafine palm oil ash and blast furnace slag. The addition of up to $20 \mathrm{wt} . \%$ ultrafine palm oil fuel ash to the slag-based mixes increased the compressive strength after 28 days of thermal curing, but higher volumes of ash slightly reduced mechanical performance. Conversely, Islam et al. ${ }^{121}$ identified that the optimal level of blast furnace slag substitution by a coarser palm oil ash was $30 \mathrm{wt} . \%$. Blended palm oil ash-slag alkaliactivated cements exhibited good chemical resistance when exposed to sulfuric acid, when the content of slag was lower than $40 \mathrm{wt} . \%$ of the total binder(to minimise the degree of damage which could happen via decalcification and gypsum formation) and when the water content of the cement was held low. ${ }^{122}$

Ranjbar et al. ${ }^{123,124}$ partially replaced coal fly ash by palm oil fuel ash in alkaliactivated cements, where a delay in compressive strength development was observed as the fraction of palm oil fuel ash increased, in contrast to the trend identified in activated slag/palm oil fuel ash cements as noted above. These alkali-activated palm oil fuel ash/fly ash blended cements gained strength when exposed to temperatures of up to $500^{\circ} \mathrm{C}$ and then cooled to room temperature for testing; however, larger fractions of palm ash reduced the strength retention upon heating of these materials. High resistance to sulfuric acid exposure was also found in concretes based on these binders by Ariffin et al., ${ }^{125}$ compared with Portland cement based concretes. This was again associated with the absence of Ca-rich reaction products, which are more prone to react with the sulfuric acid to form gypsum.

Kupaei et al. ${ }^{126}$ identified an increase in the compressive strength of foamed cements as coal fly ash was partially replaced by palm oil fuel ash, which was attributed to the higher water demand of the coal ash and thus the need to add more water to achieve 
satisfactory workability, andLiu et al. ${ }^{127}$ also developed low-density structural insulating materials from this combination of precursors. Hawa et al. ${ }^{128}$ added palm oil fuel ash to alkali-activated metakaolin, which was able to decrease the tendency towards drying shrinkage of these alkali-activated cements.

The growing number of studies utilising this waste, and the positive results obtained in terms of mechanical performance and durability, elucidate that alkali-activation technology is a feasible pathway for its exploitation and the production of construction materials in palm oil producing areas, some of which are underdeveloped and in need of low-cost housing. The production volumes of palm oil fuel ash from major electricity generating facilities are also sufficient to make the production of alkali-activated concretes from the ash potentially economically viable, and the timescale on which these ashes are expected to be produced is also sufficiently long to make construction of dedicated facilities for their utilisation in construction materials appear worthwhile.

\subsection{Sugar cane bagasse ashes}

Sugar cane is thesinglemost produced crop in the world, ${ }^{100}$ with an estimated production of more than 2165 milliontonnes in $2013,{ }^{129}$ around $30 \%$ of which is produced in Brazil, with very large volumes also generated in other warm-climate regions of the Americas and Asia.These regions in general correspond to areas of high demand for construction materials, and so any by-products generated by the sugar industry would appear to be geographically well located for use in concrete production. This is highlighted in Figure 7, which compares the per-capita cement and sugar cane production for the world's top 10 sugar cane producing countries. All of these nations have relatively high per-capita cement production, correlating well with sugar cane production (circled region) except in the cases of Brazil (high sugar cane, moderate cement) and China (high cement, moderate sugar cane) as marked inFigure 7. This indicates that there is generally likely to be good availability of sugar cane

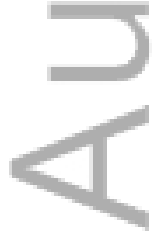


bagasse ash in areas of high demand for construction materials, which shows a strong potential for the valorisation of this waste material in construction applications.

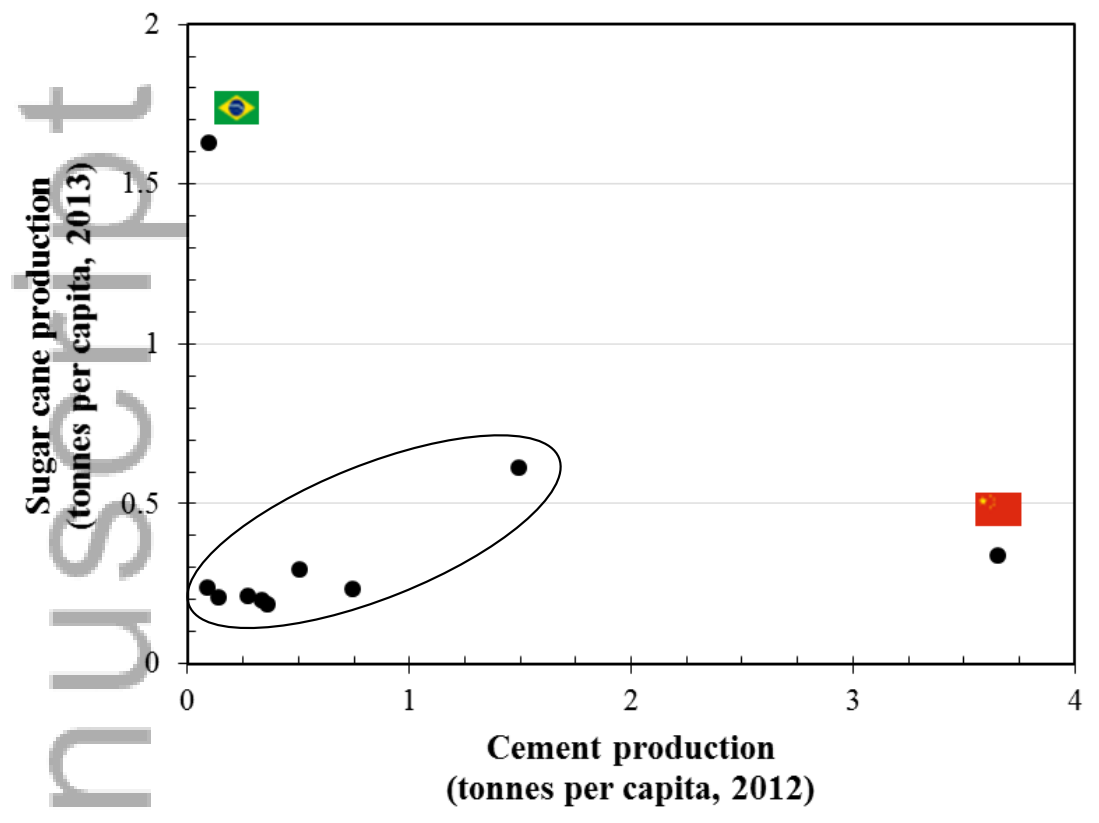

Figure 7. Comparison of sugar cane and cement production per capita (top 10 global sugar cane producers). Data from ${ }^{130-132}$

It has been reported ${ }^{133}$ that for every 10 tonnes of sugarcane crushed, a sugar factory produces nearly three tonnes of wet bagasse, which is thus a highly significant source of waste produced worldwide. Sugar cane bagasse is used for several applications, including in the production of animal feed, enzymes, amino acids, organic acids and compounds of pharmaceutical importance; ${ }^{134}$ however, it is also often utilised as fuel in sugar cane mills. Bagasse combustion producessilica-rich ashes which have been studied over the past decades as supplementary cementitious materials. ${ }^{135-139}$ In Brazil alone, the generation of sugar cane bagasse ash(SCBA)is equivalent to about $6 \%$ of nationalPortland cement production, ${ }^{140}$ which could potentially mitigate more than 
500 kilotonnes of $\mathrm{CO}_{2} \mathrm{emissions}$ per yearif the SCBAwere to beused as a partial cement replacement.

A limited number of studies have been carried out to demonstrate the utilisation of sugar cane bagasse ashes as precursors for alkali-activated cements. Castaldelli et $a l .{ }^{141}$ demonstrated that it is possible to produce alkali-activated cements based on a blend of blast furnace slag and SCBA, with compressive strengths of up to $60 \mathrm{MPa}$ after 55 days of curing at $20^{\circ} \mathrm{C}$, and low porosity. In a later study, the same group ${ }^{142}$ also produced cements from alkali-activated fly ash blended with sugar cane bagasse ashwhich had been thermally treated to reduce its content of organics. These cements developed good compressive strengths when cured at $65^{\circ} \mathrm{C}$, associated with the formation of an aluminosilicate type gel as the main reaction product.

More recently Pereira et al. ${ }^{143}$ also produced blended activated cements based on blast furnace slag and SCBA, and evaluated the durability of these binders when exposed to hydrochloric acid, acetic acid, ammonium chloride, sodium sulfate and magnesium sulfate.These cements performed much better than Portland cements when exposed to ammonium chloride, acetic acid and sodium sulfate; however,little advantage was observed when the specimens were exposed to hydrochloric acid or magnesium sulfate. The partial substitution of slag by sugar cane bagasse ash did not have a significant effect in the phase assemblage or mechanical strength development of the assessed cements. Therefore, it was proposed that this might be a feasible way to reduce the production cost of alkali-activated blast furnace slag cements by achieving good performance with lower contents of this more expensive precursor, and also to maximise the re-use of sugar cane bagasse ashes, particularly where exposure of the hardened material to certain chemically aggressive conditions is likely.

\section{$4 \quad$ Wastes from the mining and mineral industries}

\subsection{Red mud}

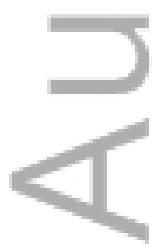


Red mud is an alkaline waste with apH between 9.2 to 12.8 in the untreated state, ${ }^{144}$ generated fromalumina extraction via the Bayer process, where the bauxite ore is treated with sodium hydroxide solutions. When most of the aluminium has been extracted from the ore, the red mud has a high quantity of entrained $\mathrm{NaOH}$, and contains iron oxides that give its red colour. This waste can contain high contents of silicon, as well as some residual aluminium whose quantity depends on the efficiency of the Bayer process operations, often present as zeolites or related aluminosilicate mineral phases. The worldwide annual generation of red mud is estimated at 120 million tonnes/year, which makes its disposal an issue of great environmental importance. ${ }^{145}$

The development of mechanical strength throughalkali-activation of red mud is limited by the low available aluminium content of most of the red mud sources which have been tested. However, the use of a more aluminium-rich red mud, ${ }^{146}$ or adding metakaolin ${ }^{147}$ or fly $\operatorname{ash}^{148,149}$ as secondary sources of aluminium,can contribute to improve the mechanical strength development of the alkali-activated binder. Kumar et $a l .{ }^{150}$ have produced paving blocks based on alkali-activated fly ash/red mud blended cements which comply with the relevant Indian national legislation (BIS IS 15658:2006) for precast concrete blocks, and with low leachability of alkalis. Alkaliactivatedblast furnace slag/red mud blended binders have also been developed, ${ }^{151-153}$ and the slag significantly increased the compressive strength of these materials.

Ye et al. ${ }^{153,154}$ identified that thermal treatment of red mud increases its reactivity in alkali-activation; however, it was still not sufficiently reactive to develop a measurable compressive strength when simply mixing the calcined red mud with water, despite its high initial alkalinity. In a following study, Ke et al. ${ }^{155}$ added $\mathrm{NaOH}$ prior to the thermal treatment of the red mud, which favoured the formation of hydraulic phases including a disordered peralkaline Na-aluminosilicate, tricalcium aluminate and \pm -dicalcium silicate. This modified red mud reacted with water, without requiring the addition of an additional alkali-activator, and hardened monoliths with a measurable compressive strength were produced. This study 
demonstrated that utilisation of red mud for producing just 'added water' alkaliactivated cements is feasible via alkali-thermal activation, although the costeffectiveness of such a process requires further investigation and a secondary source of inexpensive alkalis.

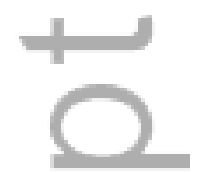

\subsection{Kaolin wastes}

Kaolin is one of the most important clay minerals exploited for the manufacture of paper $(\sim 45 \%)$, ceramics $(\sim 15 \%)$, refractories $(\sim 15 \%)$, andother products. The United States, Uzbekistan, Czech Republic, Germany and Republic of Korea are the largest producers of kaolin, with an annual total production estimated at 23 millions of metric tons. ${ }^{156}$ The clay is often extracted from open-cut mines and is processed by different treatments (thermal, mechanical or chemical) to remove impurities, enhance whiteness, and/or adjust particle size distributions and shape.Wet processing is widely used to produce kaolin products for the paper industry and in filler applications. In this process, a dispersed kaolin-water suspension is passed through screens, hydroseparators, or hydrocyclones to remove the coarser mineral particles. Thereafter, whitening to increase brightness iscarried out. The rejected kaolin sludge is now generating a considerable environmental impact due to the large areas required for its disposal. ${ }^{157,158}$ This mineral waste is formed mainly of coarse kaolinite particles and some traces of quartz and/or anatase. ${ }^{159}$

In recent years, the mining industry has become motivated to find a suitable application for the rejected kaolin sludge, with a view towards its potential valorisation. In this sense, dried kaolin waste has been assessed as an aggregate in asphalt concrete. ${ }^{160}$

The controlled thermal treatment of kaolin sludge at temperatures around $700{ }^{\circ} \mathrm{C}$ transforms the waste kaolinite into metakaolin, which is a material with higher added value. This metakaolin derived from calcined kaolin sludge (CKS) exhibits

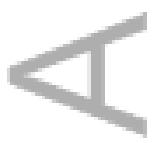


pozzolanic properties and high reactivity in cementitious systems ${ }^{161,162}$ and in zeolite synthesis. ${ }^{163,164}$

This reactivity indicates thatCKS is potentially suitable for use in the production of alkali-activated binders. Longhi et al. ${ }^{165,166}$ assessed the use of a Brazilian kaolin waste, which was thermally treated at $700{ }^{\circ} \mathrm{C}$ and ball milled, then activated with sodium silicate solution. The resulting geopolymers exhibited high mechanical performance (up to $70 \mathrm{MPa}$ in compression), comparable to the strengths achieved through the use of a much more expensive commercial metakaolin as precursor, and the coarser particle size of the CKS is actually to some extent beneficial in improving the fresh-state properties of the geopolymer mixes. Alkali-activation thus appears to be a technological and feasible solution for the valorisation of this industrial waste.

\subsection{Low purity clays}

The search for low cost or easily available materials for production ofalkali-activated cements has led to the assessment of 'normal clays' such as montmorillonites, smectites and illites, among others. These clays are widely available all over the world, and may show reactivity with alkalis after thermal activation. ${ }^{167-169}$ However, they tend to be more variable in composition and mineralogy than commercial kaolinites, and the parameters of the thermal activation process must be particularly precisely controlled in order to reach high reactivity. ${ }^{170}$ So, extensive research is required to elucidate the factors that control the performance and long term stability of alkali-activated cements based on normal clays.

(

Two particular types of clays, bentonite and lateritic soils, are the object of alkaliactivation research in several countries. Laterites are soil types rich in iron and aluminium, formed in hot and wet tropical areas, and contain kaolinite in which a high proportion of $\mathrm{Al}^{3+}$ is replaced by $\mathrm{Fe}^{2+}$ or $\mathrm{Fe}^{3+} \cdot{ }^{171}$ When thermally treated between $750^{\circ} \mathrm{C}$ and $800^{\circ} \mathrm{C}$, the kaolinite and gibbsite present in the soil transform into metakaolin and amorphous alumina, ${ }^{172}$ which show pozzolanic activity and can be used as supplementary cementitious materials for concrete production. ${ }^{173}$ In recent 
years, there has been a growing interest producing alkali-activated cements based on calcined lateritic soils. Silva-Neto et al. ${ }^{174}$ and Gomes et al. ${ }^{175}$ havedemonstrated that Brazilian laterites are suitable precursors for alkali-activated cement production. In these systems the iron is seen to play a significant role in the development of the binding phasês, so that iron distribution in the aluminosilicate type gels appears to occur via formation of Fe-Al-Si oxide amorphous structures. Although the structural role of $\mathrm{Fe}^{3+}$ as a substituent for $\mathrm{Al}^{3+}$ in these aluminosilicate gels remains poorly understood, screening methodologies such as those presented by McIntosh et al. ${ }^{176}$ for the Fe-rich kaolinite resources of Northern Ireland offer the possibility to identify and exploit these lower-purity clay deposits, which would otherwise be of little or no economic value, as precursors for alkali-activation. The potassium silicate-activated mixes described in that study reached strengths as high as $89 \mathrm{MPa}$ at 7 days.

Lassinantti-Gualtieri et al. ${ }^{177}$ assessed the effectiveness of either acidic (phosphoric acid) or basic (sodium silicate) activation of laterite soils, before and after thermal treatment,to produce alkali-activated cements. It was demonstrated that thermal treatment of the laterite is required prior to chemical activation, and that both pathways of activation could promote the formation of hardened solid binders from a suitably calcined precursor. The acid phosphate chemistry described in this context appears in some way similar to the 'Ceramicrete' phosphate-bonded ceramics, and also to published work based on the combination of phosphoric acid and pure metakaolin, ${ }^{178}$ but the cost of phosphoric acid is rather high and sois likely to restrict its use in large-scale applications.

Bentonite is a montmorillonite type claythat can be thermally treated to produce apozzolan, and can be used by the construction industry as a supplementary cementitious material. ${ }^{179,180}$ There exist a limited number of studies related to alkaliactivation of thermally treated bentonite. Hu et al. ${ }^{181}$ carried out a study using nontreated bentonite as an additive (less than $15 \mathrm{wt} . \%$ ) in alkali-activated fly ash binders, identifying that this clay acted as a filler and contributed to densify these binders. Chervonnyi et al. ${ }^{182}$ utilised alkali-activated thermally treated bentonite for the 
solidification of low-level radioactive ashes from the Chernobyl accident region. Monoliths achieved 12MPa after 28 days of curing, and showed significantly lower leachability of strontium compared with Portland cement grouts. This suggested that alkali-activated cements based on bentonites could be an environmentally beneficial process for treatment of radioactive wastes.

More recently García-Lodeiro et al. ${ }^{183}$ evaluated thermally treated bentonites as the sole precursor for producing alkali-activated cements. This study elucidated that effectively alkali-activated thermally treated bentonites produce hardened solids, whose strength is dependent on the availability of $\mathrm{Si}$ and $\mathrm{Al}$ in the system. The addition of highly soluble sources of $\mathrm{Al}$, such as sodium aluminate, improved the compressive strength of these binders.

The alkali-activation of low cost normal clays such as bentonites and laterites, which are highly available in growing countries where the need for infrastructure ispressingand will increase in coming years, seems a viable alternative pathway to produce affordable construction materials.

\subsection{Other mining and mineral wastes}

Mining wastes are fine and coarse mineral materials resulting from mining and mineralprocessesoperations, which usually are collected, transported and placed in large heaps or dams. ${ }^{184}$ Approximately seven billion tons of tailings are produced worldwide each year, much of which consists of clay-rich minerals which are impure and considered to be of low value, but which may offer significant value as precursors for alkali-activation, particularly in applications such as mine backfilling where the ability to replace Portland cement offers the possibility to reduce costs and gain environmental benefit. ${ }^{185}$

One such source of low purity clays from the mining industry is a tungsten mine waste from Portugal, which is an aluminosilicate rich in clay minerals and iron. When thermally treated at $950{ }^{\circ} \mathrm{C}$, dehydroxylation and amorphisation of this waste has 
been identified, ${ }^{186}$ consistent with its significant content of phyllosilicate clay minerals. Pacheco-Torgal et al. ${ }^{187}$ evaluated the effect of $\mathrm{NaOH}$ and $\mathrm{Ca}(\mathrm{OH})_{2}$ concentrations on the mechanical performance of alkali-activated calcined tizatugsten mine waste, and used these results to develop a material with an optimised activator content, ${ }^{186}$ as well as lower shrinkage than Portland cement andlow water penetration. Conversely, the blending of sodium carbonate with the tungsten mine waste hindered the dehydroxylation of the waste, and even though a high compressive strength was achieved at early times of curing, a reduction in the stability of these cements was observed when immersed in water. ${ }^{188}$

Other mining wastes that have been utilised to produce alkali-activated cements include those obtained from copper mining, which are rich in feldspars and can be used in the production of bricks; ${ }^{189,190}$ heavy metals are also able to be effectively immobilised in these materials. ${ }^{191}$ The addition of a small quantity of sodium aluminate can enhance the strength development of these materials, depending on the temperature of curing, ${ }^{190}$ which suggests that the availability of aluminium from the mining wastes was limiting the performance achieved. For this reason, the combination of copper mine wastes or tailings with other aluminous materials has also been identified as advantageous in alkali-activation; Zhang et al. ${ }^{192}$ produced copper mine tailings/fly ash-based alkali-activated cements, where fly ash addition promoted high compressive strengths and relatively rapid strength development.Ahmari et al. ${ }^{193}$ produced alkali-activated cements by blending copper mine tailings with low-calcium flash-furnace copper smelter slag and an alkali activator. The addition of the smelter slag enhanced the mechanical strength and promoted the formation of a denser microstructure, as a consequence of the high solubility of silica from the slag and its fine particle size distribution. However, elevated temperature curing was required to accelerate the hardening of the specimens. Ren et al. ${ }^{194}$ also showed thataluminium sludge could be effective as a secondāry source of $\mathrm{Al}_{2} \mathrm{O}_{3}$ in an alkali-activated blend with copper mine tailings, todecrease the overall $\mathrm{Si} / \mathrm{Al}$ molar ratio and improve the performance of the resulting binders.

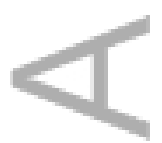


Caballero et al. ${ }^{195}$ utilised a silica-rich gold mining waste, derived from the grinding and subsequent separation of sulfides from quartzo-feldspathic gneiss, as the main precursor to produce alkali-activated cements, with minor Portland cement addition to accelerate early reaction. These cements developed compressive strengths of up to 45 $\mathrm{MPa}$, and presented a high resistance to when exposed to sulphuric acid, but degradation of the specimens was identified upon exposure to nitric acid. In both sodium and magnesium sulfate solutions, these cements gained strength at extended times of immersion. In another study, the alkali-activation of thermally treated halloysite blended with volcanic glass and gold extraction tails was reported by Barrie et al. ${ }^{196}$ The cements thus produced developed good compressive strength (30 MPa), and immobilisation of zinc and lead present in the tails was achieved in these alkaliactivated cements. However, high leachability of arsenic and copper was identified in these specimens, which makes the material unsuitable for construction purposes, and so it was suggested that these activated cements may bemost effectively used for back-fill purposes or as capping materials. ${ }^{196}$

\section{Wastes from other industries}

\subsection{Coal bottom ashes}

Coal is the most abundant fossil fuel used for electricity generation, and its relatively low cost and large deposits represent a reliable source of energy. Around 7.1 billion of tonnes of coal is used worldwide every year. ${ }^{197}$ The main coal combustion wastes (or by-products) are fly ash, bottom ash, flue-gas desulfurisationproducts, and boiler slag. These wastes are mainly used as raw materials for the construction industry in the production of clinker or blended cements and concretes, in civil engineering (as subgrade stabilisation, pavement base course, and structural fill), and forsite restoration in open cast mining. ${ }^{198,199}$ However, the majority of these materials are eventually sent to landfill rather than being effectively re-used.

Coal fly ash (FA) is currently playing an important role in the concrete and cement market due to its low cost and pozzolanic reactivity, ${ }^{200}$ and has been discussed in the

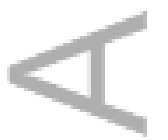


context of its use in alkali-activation in several major reviews, so will not be the focus of discussion here. The second most important residue generated during coal combustion is coal bottom ash (CBA), which represents up to the $20 \%$ of the total ash generated. The CBA is collected at the bottom of the furnace and consists of larger, granular and glassy heavier particles. The total production of CBA in the European Union (EU15) is estimated to be $\sim 4.1 \mathrm{Mt}$ per annum, and only $46 \%$ of this is re-used efficiently. ${ }^{201}$ In the U.S., the total production of CBA reported in 2012 was $14.1 \mathrm{Mt}$ with a utilisation rate of $38.8 \%{ }^{202}$

Although FA and CBA have similar origins, their physical and chemical features differ widely. In particular, the CBA generally contains more heavy metals than the fly ash. Therefore, in some countries, the most recent regulations and policies for the safe disposal of coal combustion wastes have modified the management of CBA. ${ }^{203}$ Taking into account the large volume that is disposed in landfill, CBA is becoming an environmental and economical concern due to the large land areas used, as well as the ground and water contamination by leaching of trace elements. CBA has been used as an artificial aggregate in concrete bysubstitutionforsand, ${ }^{204,205}$ and also shows some pozzolanic reactivity, which can be improved through mechanical treatment. ${ }^{206,207}$ However, its use as a supplementary cementitious material has not been widely accepted due to its high porosity and low density, which have a negative effect on water demand. ${ }^{207}$

Asignificant alternative route for the valorisation of $\mathrm{CBA}$ is itspotential use as a raw material for the production of alkali-activated cements, as a consequence of its relatively high contentof $\mathrm{SiO}_{2}$ and $\mathrm{Al}_{2} \mathrm{O}_{3}$ in reactive form.

However, Chindaprasirt et al. ${ }^{208}$ provideda comparative assessment of alkali-activated binders produced with FA or CBA (both with $\mathrm{CaO}$ contents of $\sim 16.5 \%$ ), and found thatthe compressive strength achieved by the FA-based binders was considerably higher than was achieved with the CBA, due to the higher reactivity and higher content of amorphous phases present in the FA.As wasnoted above related to the utilisation of $\mathrm{CBA}$ as a pozzolan, the application of mechanical treatment can also 
increase its reactivity in alkali-activation, and thus mortars with improved mechanical performance and higher workability can be obtained. ${ }^{209}$ The differences in chemical composition, degree of amorphicity and particle size distribution of the diverse CBAs generated in different thermoelectric plants lead to an intrinsically high variability in the development and optimisation of alkali-activated binder formulations based on these materials.

Because the development of CBA-based alkali-activated binders has increased only recently, there exist few reports related to the performance of these materials when exposed to - aggressive environments. Sata et al. $^{210}$ studied alkali-activated bindersderived from a milled CBA exposed to $3 \% \mathrm{H}_{2} \mathrm{SO}_{4}$ and $5 \% \mathrm{Na}_{2} \mathrm{SO}_{4}$ solutions. The mortars exhibited excellent performance after immersion in these sulfate solutions, which is even better when finer CBA is used due to the finer pore size distribution and consequent lower permeability of the binders. ${ }^{211}$

As an alternative method to using alkali-activation directly to convert waste into cementitious binders, Geetha and Ramamurthy ${ }^{212}$ reported the effectiveness of a pelletisation method for the production of artificial coarse aggregates through the alkali-activation of CBA using blends of $\mathrm{NaOH}$, sodium silicate and $\mathrm{Ca}(\mathrm{OH})_{2}$. Although their results elucidate a novel potential route to valorisation and application of $\mathrm{CBA}$, further assessment is required in order to understand the performance of these synthetic aggregates in concrete mixes, as well as the economic and environmental feasibility of their production through the alkali activation of CBA.

In general, the volume of CBA generated worldwide is continuing to increase as the worldwide demand for energy grows, and the development of new methods for the safe disposal or valorisation of this material is essential. Its chemical and physical properties are more challenging, and more variable, than those of the fly ash which results from the same coal combustion processes, but this also means that the competition from other potential users of $\mathrm{CBA}$ is much lower and so it offers significant potential for development in future years. 


\subsection{Paper sludge ash}

It has been estimated that one tonne of paper sludge is generated per three tonnes of paper produced, ${ }^{213}$ and considering the total worldwideannual production of 403 million tonnes of paper, ${ }^{214}$ this means that more than 130 million tonnes of paper sludge need to be valorised or disposed worldwide each year. Some of the strategiesadopted for the management of paper industry wastes include incineration with energy recovery, pyrolysis, steam reforming, production of mineral fillers for building materials such as cement, among others. ${ }^{213}$ In particular, paper sludge ash is a by-product derived from the incineration of paper sludge, which can contain varying quantities of thermally-amorphised clays and partially decomposed calcium carbonate, depending on the proportions of clay and calcite used in paper production. The potential use of this ash as a supplementary cementitious material has been studied over the past decade, ${ }^{215,216}$ considering the importance of both calcined clays and limestone as mineral admixtures for Portland cement.

A limited number of studies have been carried out using paper sludge ashes as a precursor for alkali-activated cements. In preliminary work, Yan et al. ${ }^{217}$ identified that the partial substitution of fly ash with dried (uncalcined) paper sludge reduced the workability and compressive strength of the alkali-activated cements; however, it did promote a refinement of the pore structure which led to a reduced drying shrinkage of the material.Antunes Boca Santa et al. ${ }^{218}$ produced alkali-activated calcined paper sludge cements blended with coal bottom ashes, as the calcined paper sludge utilised was partially crystalline and not highly reactive. Higher contents of bottom ash contributed to increase the mechanical strength and density of the cements.

More recently, Gluth et $a{ }^{219}{ }^{219}$ reported higher compressive strengths in water-hydrated paper sludge ash paste compared to the same ash activated by $\mathrm{NaOH}$ or $\mathrm{KOH}$, after 28days of curing. All of the portlandite formed by hydration of the free lime in the ash was consumed during the first 7 days of curing. Bernal et al. ${ }^{220}$ utilised a paper sludge

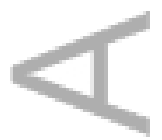


ash rich in free lime as a precursor for production of alkali-activated cements. This particular paper sludge ash was highly reactive, and when combined with either water or an alkaline solution, it formed hydrated reaction products including AFm-type phases, portlandite and a highly disordered C-A-S-H type phase. The inclusion of an alkaline solution (either sodium hydroxide or silicate) increased the dissolution rate of free lime, and consequently favoured the formation of more Ca-rich phases compared to the water-hydrated paper sludge ash.

Considering the significant differences in composition, particularly the content of free lime, between paper sludge ashes from different sources, it cannot be stated that this waste will generically be suitable for production of alkali-activated cements, as the activation reaction will proceed in a different way depending on the content of calcium present in the ash. However, with the correct combination of ash, activator and secondary (likely siliceous) precursors, it does appear possible to produce goodquality alkali-activated materials from paper sludge ash, and this would seem to be a high value-added end usage for these ashes.

\subsection{Spent fluid catalytic cracking catalyst}

Fluid catalytic cracking catalyst (Figure 9) is an aluminosilicate product, often based on a zeolitic framework, used extensively in oil refineries. Once this catalyst loses its activity(becomes 'spent'), and if it cannot be effectively or economically regenerated, it is discarded and treated as waste. This waste catalyst has been studied as a potential

supplementary cementitious material for the production of blended cements, ${ }^{221,222}$ and high performance mortars and concretes have been produced in this manner. The reactivity of this waste varies depending on the nature of the initial catalyst used, ${ }^{221,223}$ therefore optimisation studies are required when using materials from different sources. The production of this waste is relatively low, around 800,000 tons per year worldwide in $2010,{ }^{224}$ which has limited its large-scale adoption as a partial replacement of Portland cements in concrete production.

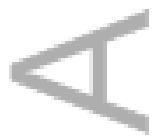




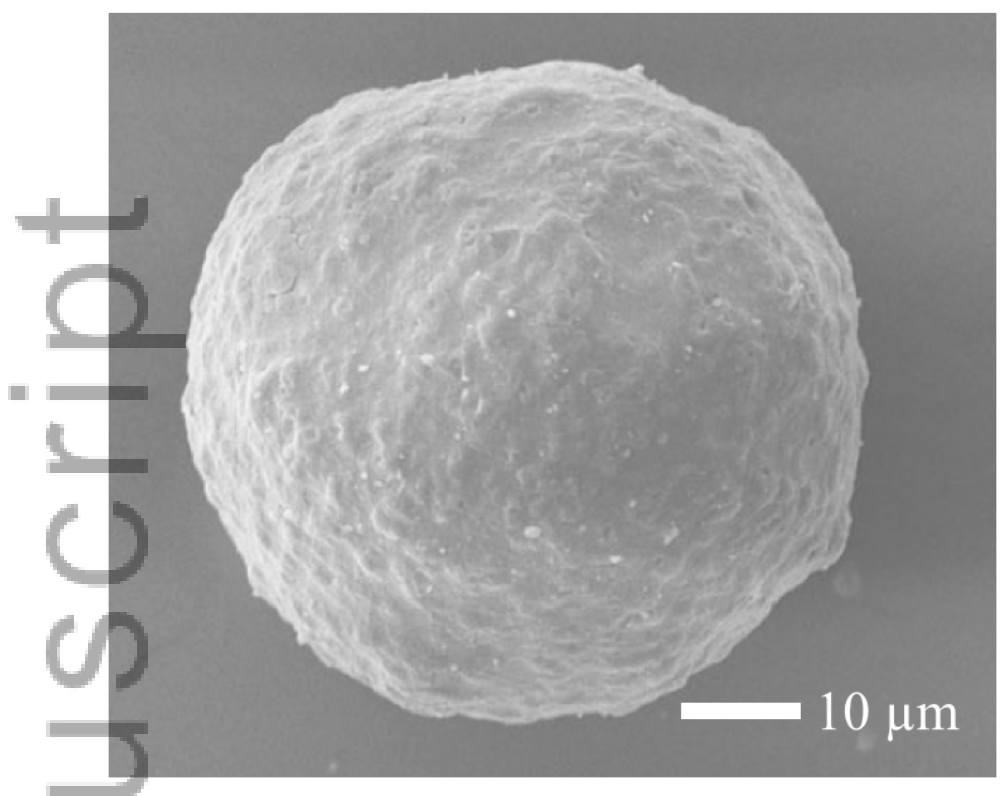

Figure 8. SEM image of a spent fluid cracking catalyst particle, showing a spherical particle morphology and absence of micron-scale pores, as well as bright regions which are likely to correspond to high local concentrations of heavy metals. From Bare et al., ${ }^{225}$ copyright John Wiley \& Sons.

In recent years, Tashima et al., ${ }^{226,227}$ Rodríguez et al. ${ }^{228}$ and Trochez et al. ${ }^{229}$ utilised fluid catalytic cracking catalyst residues as sole precursors for producing alkali activated cements. These studies have been focused on evaluating the effects of different formulation parameters on the microstructural development of these materials, their phase assemblage and compressive strength. There is a good consensus that this waste is a suitable precursor for producing alkali-activated cements, which can develop a high compressive strength depending on the formulation adopted for its production. In the case of Tashima et al. ${ }^{226,227}$ high temperature curing $\left(65^{\circ} \mathrm{C}\right)$ was utilised, while Rodríguez et al. ${ }^{228}$ and Trochez et $a l .{ }^{229}$ cured their samples at $40^{\circ} \mathrm{C}$ and $25^{\circ} \mathrm{C}$, respectively, and the materials obtained 
developed compressive strengths comparable to those reported for high temperature cured specimens. Significant differences in the nature of the alkali activation reaction products betweensources of spent fluid catalytic cracking catalyst waste have been identified across these studies, and therefore it is necessary to identify the characteristics of the waste, particularly mineralogy and particle size distribution, that control its performance when used as a precursor for alkali-activated cements.

The alkali-activation of this waste might be of interest for its treatment or valorisation, depending on the content of toxic and hazardous elements present, as both catalytic heavy metals and contaminants deposited on the catalyst in use can be important in determining the availability of hazardous species from the waste catalysts. Further investigation of these systems is required to elucidate whether these cements can develop specialised technical properties to make their development sufficiently attractive for commercial purposes.

\section{Summary and general considerations}

Table 1 provides a summary of the nature and production of the wastes discussed in this review, and their characteristics which are particularly relevant to use in the production of alkali-activated cements and concretes.

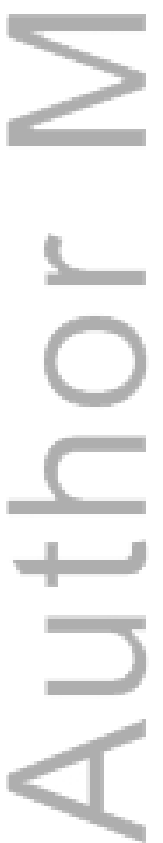


Table 1. Summary of wastes considered, and key factors defining their utilisation in alkali-activated cement materials.

\begin{tabular}{|c|c|c|c|c|c|}
\hline & Quantities available & $\begin{array}{l}\text { Use in alkali } \\
\text { activation } \\
\text { technology }\end{array}$ & Disadvantages if used in alkali-activation & $\begin{array}{c}\text { Potential advantages for use in } \\
\text { alkali-activation }\end{array}$ & $\begin{array}{c}\text { Waste } \\
\text { classification }_{0}^{23}\end{array}$ \\
\hline $\begin{array}{l}\text { Ashes from } \\
\text { municipal } \\
\text { waste } \\
\text { incineration }\end{array}$ & $\begin{array}{l}\text { EU-27 incinerates } \sim 58 \mathrm{Mt} \text { of } \mathrm{MSW}(2012) \text {, } \\
\text { producing between } 6-18 \mathrm{Mt} \text { of BA. } .^{231} \\
\text { The main cities in China generated more than } \\
172 \mathrm{Mt} \text { in 2014. } \\
\text { The US generated } 254 \mathrm{Mt} \text { of MSW in } 2013 \text {, } \\
\text { where } 13 \% \%(\sim 33 \mathrm{Mt}) \text { was incinerated and } \sim 8 \\
\text { Mt of BA was produced. }{ }^{.5}\end{array}$ & $\begin{array}{l}\text { As precursor. } \\
\text { As a secondary } \\
\text { precursor } \\
\text { As aggregate }\end{array}$ & 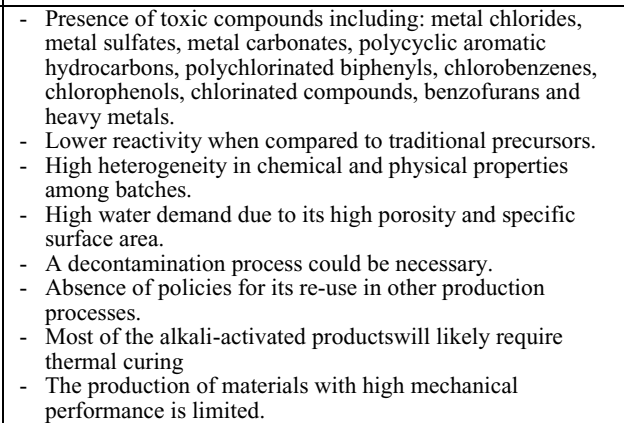 & $\begin{array}{l}\text { - Reduction of harmful substances } \\
\text { released to the environment due to their } \\
\text { encapsulation. } \\
\text { - High interest to find alternative routes } \\
\text { for disposal. }\end{array}$ & $\begin{array}{l}\text { 19.01.11/19.01.12: } \\
\text { Mirror hazardous } \\
\text { Mirror non- } \\
\text { hazardous }\end{array}$ \\
\hline $\begin{array}{l}\text { Ceramic and } \\
\text { demolition } \\
\text { wastes }\end{array}$ & 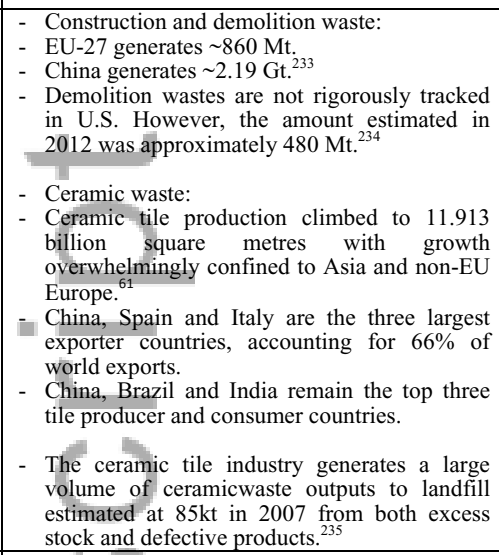 & $\begin{array}{l}\text { As precursor } \\
\text { As a secondary } \\
\text { precursor } \\
\text { As aggregate }\end{array}$ & $\begin{array}{l}\text { Construction and demolition waste: } \\
\text { - High heterogeneneity in chemical and physical properties. } \\
\text { - Requirement of a classification process due to the presence } \\
\text { of different materials (wood, plastice, glass, metal, etc), as } \\
\text { well as a milling treatment. } \\
\text { - Low reactivity when compared to other precursors. } \\
\text { - The alkalial-activated productswill likely require thermal } \\
\text { curing. } \\
\\
\text { Ceramic waste: } \\
\text { - Low reactivity when compared to other precursors. }\end{array}$ & $\begin{array}{l}\text { Construction and demolition waste: } \\
\text { - High interest to find alternative routes } \\
\text { for disposal. } \\
\text { Ceramic waste: } \\
\text { - Better homogeneity in chemical and } \\
\text { physical properties when compared to } \\
\text { demolition wastes }\end{array}$ & $\begin{array}{l}\text { 17.01/17.01.07: } \\
\text { Mirror non- } \\
\text { hazardous }\end{array}$ \\
\hline $\begin{array}{l}\text { Wastes or } \\
\text { sediments } \\
\text { from water } \\
\text { plants }\end{array}$ & $\begin{array}{l}\text { According to the FAO/AQUASTAT database, } \text {, }^{236} \\
\text { the values reported between } 2008-2015 \text { for } \\
\text { municipal waste water production are: } \\
\text { Africa: } 12.47 \mathrm{Gt} / \mathrm{y} \text {; Americas: } 94.27 \mathrm{Gt} / \mathrm{y} \text {; Asia: } \\
123.46 \mathrm{Gt} / \mathrm{y} \text {; EU: } 35.54 \mathrm{Gt} / \mathrm{y} \text {. } \\
\text { The estimated sewage sludge production rates in } \\
\text { dry metric tons per annum are: } \\
\text { EU-27. } 8909 \text { (2010); } \\
\text { US: } 6514 \text { (2004), and China: } 2966 \text { (2006). }{ }^{237}\end{array}$ & $\begin{array}{l}\text { As a secondary } \\
\text { precursor } \\
\text { Immobilisation }\end{array}$ & $\begin{array}{l}\text { - Limited availability of sewage sludge. } \\
\text { - Low reactivity due to its low content of amorphous } \\
\text { aluminosilicate compounds. } \\
\text { - Requires the use of a primary aluminosilicate precursor } \\
\text { with high reactivity. } \\
\text { - Presence of heavy metals (including } \mathrm{Zn}, \mathrm{Pb}, \mathrm{Cd}, \mathrm{Cu}, \mathrm{Hg} \text {, } \\
\mathrm{Zn} \text {, and Ni). } \\
\text { - Depending on its mineral composition a thermal process } \\
\text { counld be required (particularly for clay-rich sediment } \\
\text { sludges). } \\
\text { - Waste water treatment capacity is strongly related to } \\
\text { national development. } \\
\text { - Absence of policies for its re-use in other production } \\
\text { processes. } \\
\text { - The alkali-activated productswill likely require thermal } \\
\text { curing } \\
\text { - The production of materials with high mechanical } \\
\text { performance is limited. }\end{array}$ & $\begin{array}{l}\text { Reduction of harmful substances released } \\
\text { to the environment due to their } \\
\text { encapsulation. }\end{array}$ & $\begin{array}{l}\text { 9.02.06/19.08.12: } \\
\text { Mirror hazardous } \\
\text { Mirror non- } \\
\text { hazardous }\end{array}$ \\
\hline Waste glass & $\begin{array}{l}\text { EU-28 glass production } 22.85 \mathrm{Mt} \text { with a } \\
\text { recycling rate of } 71 \%(2013)^{2.38} \\
\text { In U.S. the glass container generation and } \\
\text { recovery in } 22012 \text { were } 11.57 \mathrm{Mt} \text { and } 3.2 \mathrm{Mt} \text {, } \\
\text { respectively. }{ }^{239}\end{array}$ & $\begin{array}{l}\text { As a source of } \\
\mathrm{SiO}_{2} \text { for the } \\
\text { production of } \\
\text { the alkali } \\
\text { activator }\end{array}$ & $\begin{array}{l}\text { - Limited availability of the residue. } \\
\text { - Requirement for a classification process } \\
\text { - Presence of high content of } \mathrm{Hg} \text { when the waste contains } \\
\text { used fluorescent lamps. } \\
\text { - Low volumes of waste can be valorised due to the low } \\
\text { amount of extra SiO } \mathrm{S} \text { required during alkali activation. } \\
\text { - Chemical dissolution of amorphous phases can be required. }\end{array}$ & $\begin{array}{l}\text { - There exist targets to achieve higher } \\
\text { reuse rate } \\
\text { - Reduction of cost of binder production } \\
\text { due to the substitution of waterglass, } \\
\text { which is the component with the } \\
\text { highest price. } \\
\text { - Improved performance of alkali- } \\
\text { activated systems when used as a } \\
\text { soluble source of } \mathrm{SiO}_{2} \text {. }\end{array}$ & $\begin{array}{l}\text { 15.01.07/19.12.05/ } \\
\text { 20.01.02: Absolute } \\
\text { non-hazardous } \\
\text { 17.02.02: Mirror- } \\
\text { non hazardous }\end{array}$ \\
\hline Rice husk ash & $\begin{array}{l}\text { In } 2014 \text { the global production of paddy rice was } \\
746 \text { million metric tonnes. } 100 \text { Assuming that } \\
20 \% \text { of paddy rice is husk, } \sim 150 \text { Mt of this } \\
\text { residue was generated. When the husk is burned, } \\
25 \% \text { of ashes is generated, which represents } \sim 38 \\
\text { Mt. }\end{array}$ & $\begin{array}{l}\text { As a source of } \\
\mathrm{SiO}_{2} \text { for the } \\
\text { production of } \\
\text { the alkali } \\
\text { activator. }\end{array}$ & $\begin{array}{l}\text { - Depending on the control of the thermal process, high } \\
\text { contents of unburned material can be obtained. } \\
\text { - Other potential applications are available, which could } \\
\text { increase cost. } \\
\text { - The transsort cost of the residue can be high due to its low } \\
\text { density. } \\
\text { - Activator solutions can exhibit a dark color, which might } \\
\text { affect the aesthetics of the final product. } \\
\text { - Requires an extra investment within the alkali-activation } \\
\text { technologylprocess for its dissolution in order to obtain a } \\
\text { high quality activator. } \\
\text { - Lower volume utilisation when compared to materials used } \\
\text { as precursors, due to the low requirements for soluble } \\
\text { silicates during the activation. }\end{array}$ & $\begin{array}{l}\text { - Reduction of cost of binder production } \\
\text { due to the substitution of waterglass } \\
\text { solution, which is the component with } \\
\text { the highest price. } \\
\text { - Alkaliactivator with a specific } \\
\mathrm{M}_{2} \mathrm{O} / \mathrm{Si} \mathrm{O}_{\mathrm{O}} \text { ratio can be produced. } \\
\text { - When produced under optimal } \\
\text { conditions, similar performance can be } \\
\text { achieved compared to commercial } \\
\text { soluble silicate solutions. } \\
\text { - Activator solutions with other alkaline } \\
\text { cations can be also produced. } \\
\text { - High number of reports elucidate its } \\
\text { feasibility for use in activator } \\
\text { production. }\end{array}$ & $\begin{array}{l}\text { Not specified in } \\
\text { this standard. }\end{array}$ \\
\hline $\begin{array}{l}\text { Palm oil fuel } \\
\text { ash }\end{array}$ & 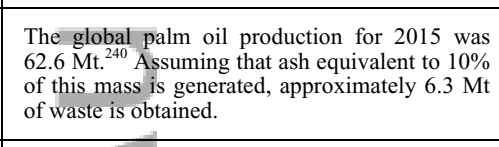 & $\begin{array}{l}\text { As precursor } \\
\text { As a secondary } \\
\text { precursor }\end{array}$ & $\begin{array}{l}\text { - Low content of reactive alumina. } \\
\text { - Most of the systems likely will require thermal curing } \\
\text { - Few reports related to its performance and effectiveness as } \\
\text { a precursor. More studies are required. }\end{array}$ & $\begin{array}{l}\text { - The presence of calcium (5-15\%) can } \\
\text { improve its performance as precursor. }\end{array}$ & $\begin{array}{l}\text { Not specified in } \\
\text { this standard. }\end{array}$ \\
\hline $\begin{array}{l}\text { Sugar cane } \\
\text { bagasse ash }\end{array}$ & $\begin{array}{l}\text { Brazil is the world's largest sugar cane producer } \\
\text { (around 650Mt in 2013), which corresponds to } \\
30 \% \text { of the world's production. } 29 \text { generates a } \\
\text { Brazilian sugarcane industry generates a } \\
\text { considerable amount of sugarcane bagasse ash, } \\
\text { estimated at about } 2.5 \mathrm{Mt} / \mathrm{y} \text { (Cordeiro, 2006). }\end{array}$ & $\begin{array}{l}\text { As a secondary } \\
\text { precursor }\end{array}$ & $\begin{array}{l}\text { - The content of } \mathrm{Al}_{2} \mathrm{O}_{3} \text { is not sufficient to be used as a main } \\
\text { precursor. }\end{array}$ & $\begin{array}{l}\text { - High production in markets with high } \\
\text { demand for construction materials. }\end{array}$ & $\begin{array}{l}\text { Not specified in } \\
\text { this standard. }\end{array}$ \\
\hline Red mud & $\begin{array}{l}120 \mathrm{Mt} / \mathrm{y} \text { of red mud is generated }{ }^{241} \text { and } \\
\text { currently a quantity in storage of more than } 2.7 \\
\mathrm{Bt} \text { is estimated. }{ }^{144}\end{array}$ & $\begin{array}{l}\text { As precursor } \\
\text { As a secondary } \\
\text { precursor }\end{array}$ & $\begin{array}{l}\text { - High content of } \mathrm{Fe}_{2} \mathrm{O}_{3} \text {, whose participation during the } \\
\text { alkali-activation technology and mechanical performance } \\
\text { improvement is not well understood (may be positive or } \\
\text { negative). } \\
\text { - According to the efficiency and effectiveness of the Bayer } \\
\text { process, the content of reactive } \mathrm{Al}_{2} \mathrm{O}_{3} \text { can be extremely low. }\end{array}$ & $\begin{array}{l}\text { - After thermal treatment the red mud can } \\
\text { be considered a good alternative to } \\
\text { produce one-part alkali-activated } \\
\text { systems (just adding water).155 } \\
\text { - Alkaline residue (mainly with high } \\
\text { contents of dissolved NaOH). } \\
\end{array}$ & $\begin{array}{l}\text { 01.03.09: Mirror } \\
\text { non-hazardous }\end{array}$ \\
\hline Kaolin wastes & 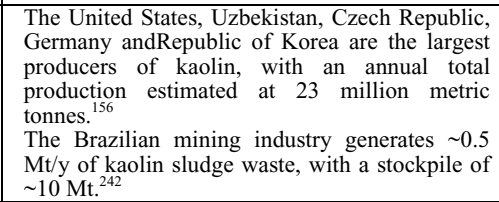 & As precursor & $\begin{array}{l}\text { - Requires thermal treatment to increase its reactivity } \\
\text { - Particle shape ereduces the workability of the fresh mixtures } \\
\text { - Reactivity degree is dependent on the kaolinite content. } \\
\text { - Kaolin sludge can be re-used for other industries and } \\
\text { applications. }\end{array}$ & $\begin{array}{l}\text { - Materials with high mechanical } \\
\text { performance can be obtained (even } \\
\text { comparable to pure MK-based } \\
\text { systems). } \\
\text { - Depending on the source, the chemical } \\
\text { and mineralogical composition might } \\
\text { be homogeneous. }\end{array}$ & $\begin{array}{l}\text { Not specified in } \\
\text { this standard. }\end{array}$ \\
\hline $\begin{array}{l}\text { Coal bottom } \\
\text { ashes }\end{array}$ & $\begin{array}{l}\text { In } 2010 \text { the global production of coal } \\
\text { combustion products (CCP was estimated at } \\
780 \mathrm{Mt} \text {. Considering that the } 15 \% \text { of the } \\
\text { overall CCP is CBA, thegenerated estimated } \\
\text { value is around } 117 \mathrm{Mt} \text {. }\end{array}$ & $\begin{array}{l}\text { As precursor } \\
\text { As a secondary } \\
\text { precursor }\end{array}$ & $\begin{array}{l}\text { - Low reactivity. } \\
\text { - High heterogeneity in chemical and physical properties } \\
\text { among batches. } \\
\text { - The production of materials with high mechanical } \\
\text { performance is limited. }\end{array}$ & $\begin{array}{l}\text { - High interest to find alternative routes } \\
\text { for disposal. }\end{array}$ & $\begin{array}{l}\text { 10.01.01: Absolute } \\
\text { non-hazardous }\end{array}$ \\
\hline
\end{tabular}




\begin{tabular}{|c|c|c|c|c|c|}
\hline & 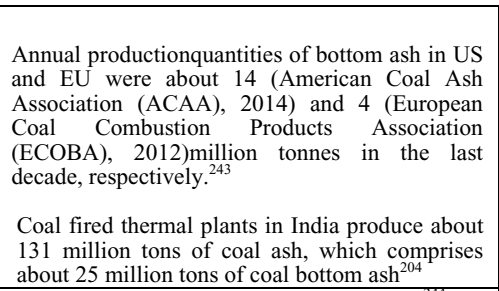 & & $\begin{array}{l}\text { - The alkali-activated productswill likely require thermal } \\
\text { curing }\end{array}$ & & \\
\hline $\begin{array}{l}\text { Paper sludge } \\
\text { ash }\end{array}$ & $\begin{array}{l}\text { Production of } 125 \mathrm{kt} \text { per annum in the UK. } \text {. }^{244} \\
\text { Confederation of European Paper Industries } \\
\text { (CEPI, 2014) states thatpulp and paper industry } \\
\text { landfill disposal has declined by } 55 \% \text { over the } \\
\text { last } 12 \text { years, from } 32.7 \text { to } 14.3 \mathrm{~kg} / \text { tonne of } \\
\text { product. }{ }^{45}\end{array}$ & $\begin{array}{l}\text { As precursor } \\
\text { As a secondary } \\
\text { precursor }\end{array}$ & $\begin{array}{l}\text { - Requires thermal treatment in order to increase its } \\
\text { reactivity. } \\
\text { - Particle yhape may reduce the workability of the fresh } \\
\text { mixtures } \\
\text { - Reactivity is dependent on the kaolinite content. }\end{array}$ & $\begin{array}{l}\text { - Thermal treatment conditions for this } \\
\text { material are similar to those used for } \\
\text { pure kaolinite } \\
\text { - Optimisation considers the } \\
\text { decomposition of organic material and } \\
\text { the prevention of free lime formation } \\
\text { from calcite. }\end{array}$ & $\begin{array}{l}\text { 03.03.02: Absolute } \\
\text { non-hazardous }\end{array}$ \\
\hline $\begin{array}{l}\text { Spent fluid } \\
\text { catalytic } \\
\text { cracking } \\
\text { catalyst }\end{array}$ & $\begin{array}{l}\text { The global production is estimated at } \sim 200 \\
\mathrm{kt} / \mathrm{y} .2+20\end{array}$ & As precursor & $\begin{array}{l}\text { - Low production when compared to the other residues. } \\
\text { - The residue requires and previous treatment in order to } \\
\text { reduce the content of harmful elements, including } \mathrm{V}, \mathrm{La} \text {, } \\
\text { and others. }\end{array}$ & $\begin{array}{l}\text { - High reactivity } \\
- \text { Homogeneity in its chemical } \\
\text { composition among different batches. } \\
\text { - The waste is constituted mainly of } \mathrm{SiO}_{2} \\
\text { and } \mathrm{Al}_{2} \mathrm{O}_{3} \text {. } \\
\text { - Materials (mainly mortars) with high } \\
\text { mechanical performance can be } \\
\text { produced. }\end{array}$ & $\begin{array}{l}\text { 16.08.04: Mirror } \\
\text { non-hazardous }\end{array}$ \\
\hline
\end{tabular}

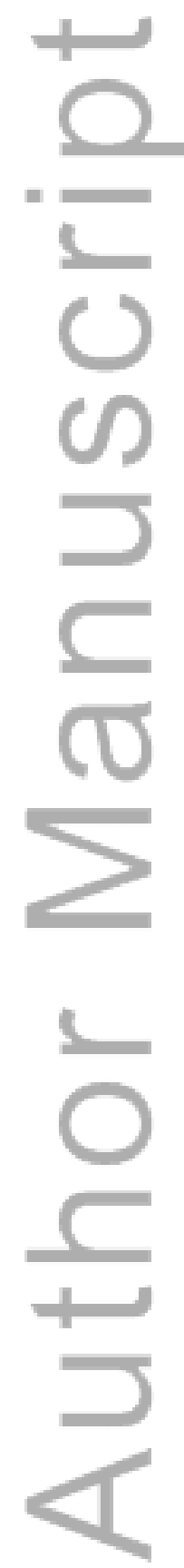


One additional key consideration, which is relevant across many of the wastes discussed in this review, is organic carbon content.The content of organic carbon, particularly when present as unburned material in wastes generated via thermal processes, must be considered carefully in the design of alkali-activated cements. The presence of a high content of porous and non-reactiveorganic particles, with a high specific surface area,significantly increases the water demand of the fresh mixtureswith aconsequent negative effect on the rheological and mechanical properties of the material. These particles can also absorb the activator solution, which reduce the alkali concentration during the reaction process. Fernandez-Jiménez and Palomo suggested that a suitable coal FA must have loss on ignition values lower than $5 \% .{ }^{247}$ However, there exist studies related to the production of alkali-activated materials using different industrial wastes or by-productsderived from thermal processes with higher contents of organic matter, including coal fly ash, ${ }^{248-251}$ coal bottom ash, ${ }^{212,252-255}$ municipal solid waste ashes, ${ }^{256,257}$ palm oil fuel ash, ${ }^{120,122,128}$ and sugar cane bagasse ash. ${ }^{141}$ Taking into account that the high content of un-reacted material reduces the effectiveness and reactivity of these wastes as precursors, blending with another more-reactive aluminosilicate may berequired. When the mechanical performance requirements for the material are higher, the use of precursors with a high content of unburned material can be restricted.

One of the methods which is often used to reduce the organic carbon content of waste ashes is a more extended (or higher temperature) combustion process, which consumes the carbon, but often at the cost of inducing partial crystallisation of the silicate or aluminosilicate phases and thus reducing their reactivity. A balance is therefore required between carbon elimination and reactivity retention, which necessitates careful process control and parametric optimisation to achieve the best results when producing alkali-activated cements using siliceous wastes.

Additionally, as discussed in section 3, it is very unlikely that pure siliceous wastes would be suitable for use as a sole precursor in alkali-activation due to their low Al content; blending with an aluminous material will always be necessary. For these 
reasons, the Si-rich wastes including SCBA, RHA and glass waste have generally been used as a source of amorphous silica for the alkaline activator. Although some of the residues included in this review have been chemically modified in order to be used as alternative alkali activators, the open literature also reports the use of other industrial waștes that are suitable for potential re-use as waste derived activators. A sodium aluminate and $\mathrm{NaOH}$-based solution from the aluminium anodising process has been successfully incorporated as an activator in fly ash / blast furnace slag blends. Even though the time of setting of these alkali-activated systems were considerably longer, these materials were able to generate a 28-day compressive strength higher than $80 \mathrm{MPa} .{ }^{258,259}$ This work, along with other reports of aluminate activation in fly ash-based alkali-activated binder systems, ${ }^{260,261}$ offers yet another opportunity for the valorisation of problematic wastes in the production of this class of construction materials.

\section{Concludingremarks}

This paper has summarised the most important research findings related to different wastes that could be used for the synthesis of alkali-activated binders. Valorisation of a wide variety of metallurgical, societal and agricultural wastes can be achieved through the use of these materials as precursorsor alternative sources of $\mathrm{SiO}_{2}$ in the activatorfor alkali-activated binders and concretes. Most alkali-activated mixes are currently based on ground granulated blast furnace slag or on fly ash, with alternative wastes generally used in lower volumes. Blending of specific wastes in defined combinations, often involving one of these better-understood materials in conjunction with another alternative material, can offer a lower-risk and potentially highly attractive path to the utilisation of a broader range of wastes, as the quality control and metals leachability issues which are often associated with many of these materials are reduced through dilution.

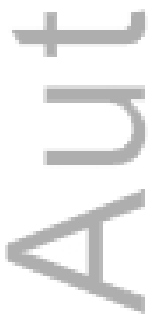


Standardisation and large-scale commercial deployment of alkali-activation technology is taking place rapidly in many jurisdictions worldwide, and although most of the mixes now being used at production scale are based on a fairly narrowselection of precursors (coal fly ash, blast furnace slag, and calcined clays), a performance-based approach to standardisation does certainly offer scope for the utilisation and valorisation of a much wider range of silicate and aluminosilicate slags as precursors for the production of alkali-activated concretes.

In developing any new material or process for large-scale deployment, it is essential to ensure that there is a robust supply chain in place. This is particularly critical in the construction materials industry because of the enormous volumes which must be processed for an operation to be economically viable; a modern cement kiln has a throughput on the order of thousands of tonnes per day, whereas in most process industries this could easily represent the annual throughput of a large plant. The cement and concrete industry, the agriculture industry and the extractive metallurgy industry, are arguably the only process sectors which are equipped to handle a such a large volume of solids as both precursor and product, and this raises important questions when analysing a potential new route to market, or a new product. When defining whether a particular alkali-activated binder formulation will be worthy of commercial attention, the key question often becomes: is it possible to make enough of this material to become commercially viable? A large number of academic studies are conducted, and published, which describe the production of an alkali-activated binder system from particular combinations of industrial wastes and chemical feedstocks. However, if a particular waste material is available only in quantities of a few tens of tonnes per day, it will be very difficult to produce a commercially useful volume of alkali-activated concrete for general construction or infrastructure applications.

This means that the production of alkali-activated concretes based on waste streams of low to moderate volume will require some form of driver other than simply the 
production of a low-cost, standard-performance concrete to enable their use in a practical and profitable context. Specific environmental or cost benefits can arise from the use of a particular solid waste material (through diversion of materials from landfill) or source of waste alkalis (replacing some of the more costly sodium silicate activator) in large-scale alkali-activated concrete production), and sometimes the performance of alkali-activated materials derived from a specific lower-volume precursor can offer attractive opportunities for niche applications. Such properties include chemical and thermal resistance, and concretes displaying good performance in these areas can command a significant price premium over standard products. This is likely to be the area in which alkali-activation of waste materials will lead to commercially and technologically significant outcomes, and will enable the true valorisation of wastes from a wide range of industries and areas of society, as has been outlined in this review.

\section{Acknowledgements}

The participation of SAB and JLP was sponsored by the Brazilian National Council for Scientific and Technological Development (CNPq) through its PVE program, and the Royal Academy of Engineering through a Newton Fund Research Collaboration Fellowship between Brazil and the UK. The participation of EDR and APK received funding from $\mathrm{CNPq}$ and the Brazilian Research Supporting Agency (CAPES), through the Young Talents for Science Program, Universal and PQ (Produtividade em Pesquisa).

\section{References}

1 United Nations Population Fund. State of world population 2009. Facing a changing world: women, population and climate. UNPFA: New York(2009).

2 John VM. On the sustainability of concrete. UNEP Ind Environ;26: 62-63 (2003).

3 Juenger MCG, Winnefeld F, Provis JL, Ideker JH. Advances in alternative cementitious binders. Cem Concr Res;41: 1232-1243 (2011).

4 Provis JL, Bernal SA. Geopolymers and related alkali-activated materials.
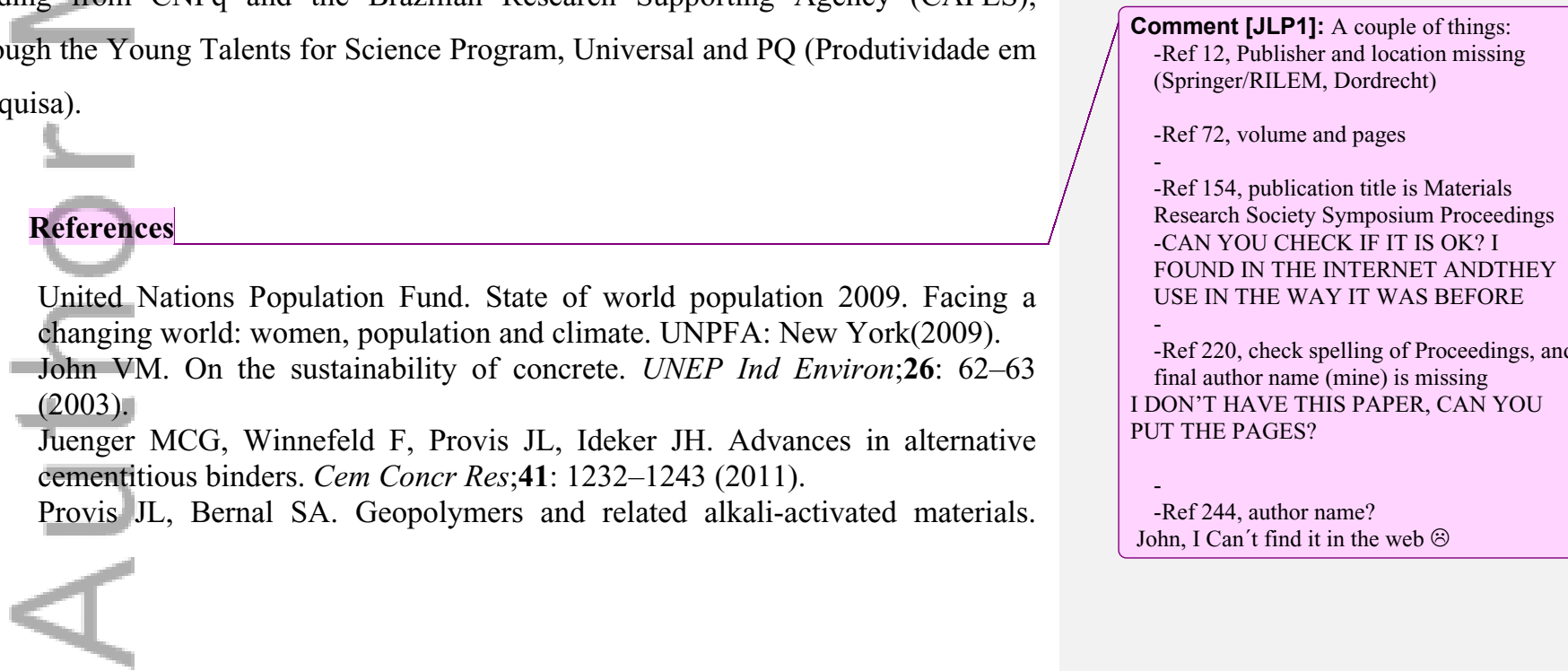
Annu Rev Mater Res;44: 299-327 (2014).

van Deventer JSJ, Provis JL, Duxson P, Brice DG. Chemical research and climate change as drivers in the commercial adoption of alkali activated materials. Waste and Biomass Valorization;1: 145-155(2010).

Duxson P, Provis JL. Designing precursors for geopolymer cements. $\mathrm{J} \mathrm{Am}$ Ceram Soc;91: 3864-3869(2008).

7 van Deventer JSJ, Provis JL, Duxson P. Technical and commercial progress in the adoption of geopolymer cement. Miner Eng;29: 89-104(2011).

Heidrich C, Feuerborn HJ, Weir A. Coal combustion products: A global perspective. In: 2013 World of Coal Ash (WOCA) Conference. Lexington, KY, pp 1-16(2013).

Shi C, Fernández-Jiménez A. Stabilization/solidification of hazardous and radioactive wastes with alkali-activated cements.J Hazard Mater; 137: 165663(2006).

10 Van Jaarsveld JGS, Van Deventer JSJ, Schwartzman A. The potential use of geopolymeric materials to immobilise toxic metals: Part II. Material and leaching characteristics. Miner Eng; 12: 75-91(1999).

11 Provis JL, Palomo A, Shi C. Advances in understanding alkali-activated materials. Cem Concr Res;78: 110-125(2015).

12 Provis JL, Van Deventer JSJ. Alkali Activated Materials State of the Art Report, RILEM TC 224-AAM.RILEM/Springer: Dordrecht(2014).

13 Bouanini S. Assessing municipal solid waste management in China. World $J$ Soc Sci;3: 71-83(2013).

14 Themelis NJ, Mussche C. Municipal solid waste management and waste-toenergy in the United States, China and Japan. In: 2nd International Academic Symposium on Enhanced Landfill Mining. Houthalen-Helchteren, Belgium, 2013.

15 United States Environmental Protection Agency. Advancing sustainable materials management: Facts and figures 2013. Assessing trends in materialgeneration, recycling and disposal in the United States. EPA: Washington DC(2015).

16 Lam CHK, Ip AWM, Barford JP, Mckay G. Use of incineration MSW ash: A review. Sustainability;2: 1943-1968 (2010).

17 UKDepartment for Environment, Food \& Rural Affairs. Incineration of municipal solid waste. Defra: London (2013).

18 Ecke H, Sakanakura H, Matsuto T, Tanaka N, Lagerkvist A. State-of-the-art treatment processes for municipal solid waste incineration residues in Japan. Waste Manag Res; 18: 41-51(2000).

19 Li X-G, Lv Y, Ma B-G, Chen Q-B, Yin X-B, Jian S-W. Utilization of municipal solid waste incineration bottom ash in blended cement. J Clean Prod;32: 96-100(2012).

20 Chimenos J., Segarra M, Fernández M., Espiell F. Characterization of the bottom ash in municipal solid waste incinerator. J Hazard Mater;64: 211222(1999).

21 Kersch C, Kraan M van der, Woerlee GF, Witkamp GJ. Municipal waste

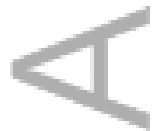


incinerator fly ash: Supercritical fluid extraction of metals. J Chem Technol Biotechnol;77: 256-259(2002).

22 Environmental Protection Agency, Ireland. European waste catalogue \& hazardous waste list. EPA: Wexford(2002).

23 Reijnders L. Disposal, uses and treatments of combustion ashes: a review. Resourc Conserv Recyc; 43: 313-336(2005).

24 Youcai Z, Lijie S, Guojian L. Chemical stabilization of MSW incinerator fly ashes. J Hazard Mater;95: 47-63(2002).

25 Park YJ, Heo J. Vitrification of fly ash from municipal solid waste incinerator. JHazard Mater;91: 83-93(2002).

26 Amutha Rani D, Gomez E, Boccaccini AR, Hao L, Deegan D, Cheeseman CR.

Plasma treatment of air pollution control residues. Waste Manag;28: 1254 62(2008).

27 Van Gerven T, Van Keer E, Arickx S, Jaspers M, Wauters G, Vandecasteele C. Carbonation of MSWI-bottom ash to decrease heavy metal leaching, in view of recycling. Waste Manag;25: 291-300(2005).

28 Allegrini E, Vadenbo C, Boldrin A, Astrup TF. Life cycle assessment of resource recovery from municipal solid waste incineration bottom ash. $J$ Environ Manag; 151: 132-43(2015).

29 Müller U, Rübner K. The microstructure of concrete made with municipal waste incinerator bottom ash as an aggregate component. Cem Concr Res;36: 1434-1443(2006).

30 Yan DYS, Tang IY, Lo IMC. Development of controlled low-strength material derived from beneficial reuse of bottom ash and sediment for green construction. Constr Build Mater;64: 201-207(2014).

31 Hassan HF. Recycling of municipal solid waste incinerator ash in hot-mix asphalt concrete. Constr Build Mater; 19: 91-98(2005).

32 Colangelo F, Messina F, Cioffi R. Recycling of MSWI fly ash by means of cementitious double step cold bonding pelletization: Technological assessment for the production of lightweight artificial aggregates. J Hazard Mater; 299: 181-191(2015).

33 Pan JR, Huang C, Kuo J-J, Lin S-H. Recycling MSWI bottom and fly ash as raw materials for Portland cement. Waste Manag;28: 1113-8(2008).

34 Kikuchi R. Recycling of municipal solid waste for cement production: pilotscale test for transforming incineration ash of solid waste into cement clinker. Resourc Conserv Recyc;31: 137-147(2001).

35 Bertolini L, Carsana M, Cassago D, Quadrio Curzio A, Collepardi M. MSWI ashes as mineral additions in concrete. Cem Concr Res;34: 1899-1906(2004).

36 Pera J, Coutaz L, Ambroise J, Chababbet M. Use of incinerator bottom ash in concrete. Cem Concr Res;27: 1-5(1997).

37 Provis JL. Immobilization of toxic waste in geopolymers. In: Provis JL, van Deventer JSJ (eds). Geopolymers: Structure, Processing, Properties and Industrial Applications. Woodhead Publishing: Cambridge, UK., pp. 423442(2009).

38 Luna Galiano Y, Fernández Pereira C, Vale J. Stabilization/solidification of a 
municipal solid waste incineration residue using fly ash-based geopolymers. $J$ Hazard Mater;185: 373-81(2011).

39 Lancellotti I, Kamseu E, Michelazzi M, Barbieri L, Corradi A, Leonelli C. Chemical stability of geopolymers containing municipal solid waste incinerator fly ash. Waste Manag;30: 673-679(2010).

40 Zheng L, Wang C, Wang W, Shi Y, Gao X. Immobilization of MSWI fly ash through geopolymerization: effects of water-wash. Waste Manag;31: 311$7(2011)$.

41 Zheng L, Wang W, Shi Y. The effects of alkaline dosage and Si/Al ratio on the immobilization of heavy metals in municipal solid waste incineration fly ashbased geopolymer. Chemosphere;79: 665-71(2010).

$42 \mathrm{Hu}$ H-Y, Liu H, Shen W-Q, Luo G-Q, Li A-J, Lu Z-L et al. Comparison of $\mathrm{CaO}$ 's effect on the fate of heavy metals during thermal treatment of two typical types of MSWI fly ashes in China. Chemosphere;93: 590-6(2013).

43 Lee WKW, van Deventer JSJ. Effects of anions on the formation of aluminosilicate gel in geopolymers. Ind Eng Chem Res;41: 4550-4558(2002).

44 Lee WKW, van Deventer JSJ. The effects of inorganic salt contamination on the strength and durability of geopolymers. Colloids Surfaces A;211: 115126(2002).

45 Ferone C, Colangelo F, Messina F, Santoro L, Cioffi R. Recycling of prewashed municipal solid waste incinerator fly ash in the manufacturing of low temperature setting geopolymer materials. Materials (Basel);6: 3420 3437(2013)

46 Diaz-Loya EI, Allouche EN, Eklund S, Joshi AR, Kupwade-Patil K. Toxicity mitigation and solidification of municipal solid waste incinerator fly ash using alkaline activated coal ash. Waste Manag;32: 1521-7(2012).

47 Reig L, Tashima MM, Soriano L, Borrachero M V., Monzó J, Payá J. Alkaline activation of ceramic waste materials. Waste Biomass Valoriz;4: 729 736(2013).

48 Dahlbo H, Bachér J, Lähtinen K, Jouttijärvi T, Suoheimo $\mathrm{P}$, Mattila $\mathrm{T}$ et al. Construction and demolition waste management - a holistic evaluation of environmental performance. J Clean Prod; 107: 333-341(2015).

49 Cazacliu B, Sampaio CH, Miltzarek G, Petter C, Le Guen L, Paranhos R et al. The potential of using air jigging to sort recycled aggregates. J Clean Prod;66: 46-53(2014).

50 Hendriks C. Suitable separation treatment of stony components in construction and demolition waste (CDW).In:International RILEM Conference on the Use of Recycled Materials in Building and Structures, RILEM Publications SARL: Bagneux, France, pp. 166-172 (2004).

51 Ulsen C, Kahn H, Hawlitschek G, Masini EA, Angulo SC. Separability studies of construction and demolition waste recycled sand. Waste Manag;33: 65662(2013).

52 Vegas I, Broos K, Nielsen P, Lambertz O, Lisbona A. Upgrading the quality of mixed recycled aggregates from construction and demolition waste by using near-infrared sorting technology. Constr Build Mater;75: 121-128(2015). 
53 De Schepper M, De Buysser K, Van Driessche I, De Belie N. The regeneration of cement out of completely recyclable concrete: Clinker production evaluation. Constr Build Mater;38: 1001-1009(2013).

54 Gastaldi D, Canonico F, Capelli L, Buzzi L, Boccaleri E, Irico S. An investigation on the recycling of hydrated cement from concrete demolition waste. Cem Concr Compos;61: 29-35(2015).

55 Schoon J, De Buysser K, Van Driessche I, De Belie N. Fines extracted from recycled concrete as alternative raw material for Portland cement clinker production. Cem Concr Compos;58: 70-80(2015).

56 Galbenis C-T, Tsimas S. Use of construction and demolition wastes as raw materials in cement clinker production. China Particuol;4: 83-85(2006).

57 Vossberg C, Mason-Jones K, Cohen B. An energetic life cycle assessment of C\&D waste and container glass recycling in Cape Town, South Africa. Resourc Conserv Recyc; 88: 39-49(2014).

58 Butera S, Christensen TH, Astrup TF. Life cycle assessment of construction and demolition waste management. Waste Manag; 44: 196-205(2015).

59 Payá J, Borrachero MV, Monzó J, Soriano L, Tashima MM. A new geopolymeric binder from hydrated-carbonated cement. Mater Lett;74: 223 225(2012).

60 Komnitsas K, Zaharaki D, Vlachou A, Bartzas G, Galetakis M. Effect of synthesis parameters on the quality of construction and demolition wastes (CDW) geopolymers. Adv Powder Technol; 26: 368-376(2015).

61 Stock D. World production and consumption of ceramic tiles. Tile Today; 85: 54-62(2014).

62 Pacheco-Torgal F, Jalali S. Reusing ceramic wastes in concrete. Constr Build Mater;24: 832-838(2010).

63 Higashiyama H, Yagishita F, Sano M, Takahashi O. Compressive strength and resistance to chloride penetration of mortars using ceramic waste as fine aggregate. Constr Build Mater;26: 96-101 (2012).

64 Ay N, Ünal M. The use of waste ceramic tile in cement production. Cem Concr Res;30: 497-499 (2000).

65 Puertas F, García-Díaz I, Barba A, Gazulla MF, Palacios M, Gómez MP et al.Ceramic wastes as alternative raw materials for Portland cement clinker production. Cem Concr Compos;30: 798-805(2008).

66 Lavat AE, Trezza MA, Poggi M. Characterization of ceramic roof tile wastes as pozzolanic admixture. Waste Manag;29: 1666-74(2009).

67 Toledo Filho RD, Gonçalves JP, Americano BB, Fairbairn EMR. Potential for use of crushed waste calcined-clay brick as a supplementary cementitious material in Brazil. Cem Concr Res;37: 1357-1365(2007).

68 Medina C, Banfill PFG, Sánchez de Rojas MI, Frías M. Rheological and calorimetric behaviour of cements blended with containing ceramic sanitary ware and construction/demolition waste. Constr Build Mater;40: 822831(2013).

69 Pavlík Z, Pavlíková M, FoY J, Kulovaná T, erný R. Reuse of waste ceramic powder with a high content of amorphous phases as partial replacement of 
Portland cement. Adv Mater Res;905: 212-215(2014).

70 Reig L, Tashima MM, Borrachero MV, Monzó J, Cheeseman CR, Payá J. Properties and microstructure of alkali-activated red clay brick waste. Constr Build Mater;43: 98-106(2013).

71 Allahverdi A, Najafi Kani E. Construction wastes as raw materials for geopolymers binders. Int J Civ Eng;7: 154-160 (2009).

72 Bernal SA, Bejarano J, Garzón C, Mejía de Gutierrez R, Delvasto S, Rodríguez ED. Performance of refractory aluminosilicate particle/fiber-reinforced geopolymer composites. Compos Part BEng; 48: 1919-1928(2012).

73 Hsiau P-C, Lo S-L. Extractabilities of heavy metals in chemically-fixed sewage sludges. J Hazard Mater;58: 73-82(1998).

74 - Fytili D, Zabaniotou A. Utilization of sewage sludge in EU application of old and new methods-A review. Renew Sustain Energy Rev;12: 116-140(2008).

75 Komnitsas K, Zaharaki D. Assessment of human and ecosystem risk due to agricultural waste compost application on soils: A review. Environ Forens; 15: 312-328(2014).

76 Monzó J, Payá J, Borrachero M V, Girbés I. Reuse of sewage sludge ashes (SSA) in cement mixtures: the effect of SSA on the workability of cement mortars. Waste Manag;23: 373-81(2003).

77 Amiralian S, Budihardjo MA, Chegenizadeh A, Nikraz H. Study of scale effect on strength characteristic of stabilised composite with sewage sludge - Part A: Preliminary study. Constr Build Mater;80: 339-345(2015).

78 Smol M, Kulczycka J, Henclik A, Gorazda K, Wzorek Z. The possible use of sewage sludge ash (SSA) in the construction industry as a way towards a circular economy. J Clean Prod;95: 45-54(2015).

79 Yamaguchi N, Ikeda K. Preparation of geopolymeric materials from sewage sludge slag with special emphasis to the matrix compositions. J Ceram Soc Japan;118: 107-112(2010).

80 Chen J-H, Huang J-S, Chang Y-W. A preliminary study of reservoir sludge as a raw material of inorganic polymers. Constr Build Mater;23: 3264 3269 (2009).

81 Chen J-H, Huang J-S, Chang Y-W. Use of reservoir sludge as a partial replacement of metakaolin in the production of geopolymers. Cem Concr Compos;33: 602-610 (2011).

82 Yang K-H, Lo C-W, Huang J-S. Production and properties of foamed reservoir sludge inorganic polymers. Cem Concr Compos;38: 50-56 (2013).

83 Ferone C, Colangelo F, Cioffi R, Montagnaro F, Santoro L. Use of reservoir clay sediments as raw materials for geopolymer binders. Adv Appl Ceram;112: 184-189 (2013).

84 Ferone C, Liguori B, Capasso I, Colangelo F, Cioffi R, Cappelletto E et al. Thermally treated clay sediments as geopolymer source material. Appl Clay Sci;107: 195-204 (2015).

85 Eurostat - Statistics Explained.http://ec.europa.eu/eurostat/statisticsexplained/index.php/Packaging_waste_statistics\#Glass (accessed 12 Jun2015)(2013).

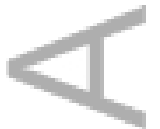


UK Environment Agency. Waste sampling and testing for disposal landfill. Bristol (2013).

87 Xie Z, Xi Y. Use of recycled glass as a raw material in the manufacture of Portland cement. Mater Struct;35: 510-515 (2002).

88 Shao Y, Lefort T, Moras S, Rodriguez D. Studies on concrete containing ground waste glass. Cem Concr Res;30: 91-100 (2000).

89 Shayan A, Xu A. Value-added utilisation of waste glass in concrete. Cem Concr Res;34: 81-89 (2004).

90 Shi C, Wu Y, Riefler C, Wang H. Characteristics and pozzolanic reactivity of glass powders. Cem Concr Res;35: 987-993 (2005).

91 Cyr M, Idir R, Poinot T. Properties of inorganic polymer (geopolymer) mortars made of glass cullet. J Mater Sci;47: 2782-2797 (2012).

92 Redden R, Neithalath N. Microstructure, strength, and moisture stability of alkali activated glass powder-based binders. Cem Concr Compos;45: 46-56 (2014).

93 Avila-López U, Almanza-Robles JM, Escalante-García JI. Investigation of novel waste glass and limestone binders using statistical methods. Constr Build Mater;82: 296-303 (2015).

94 Badanoiu AI, Al Saadi THA, Stoleriu S, Voicu G. Preparation and characterization of foamed geopolymers from waste glass and red mud. Constr Build Mater;84: 284-293 (2015).

95 Torres-Carrasco M, Palomo JG, Puertas F. Sodium silicate solutions from dissolution of glass wastes. Statistical analysis. Mater Constr;64:article e014 (2014).

96 Puertas F, Torres-Carrasco M. Use of glass waste as an activator in the preparation of alkali-activated slag. Mechanical strength and paste characterisation. Cem Concr Res;57: 95-104 (2014).

97 Torres-Carrasco M, Puertas F. Waste glass in the geopolymer preparation. Mechanical and microstructural characterisation. J Clean Prod;90: 397-408 (2015).

98 Hao H, Lin K-L, Wang D, Chao S-J, Shiu H-S, Cheng T-W et al. Recycling of solar panel waste glass as a partial replacement of meta-kaolinite in the production of geopolymers. Open Civ Eng J;6:239-248 (2012).

99 FAO/Food and Agriculture Organization of the United Nations. Rice Market Monitor - January 2013. Trade Mark Div; XVI: 38 (2013).

$100 \mathrm{FAO} /$ Food and Agriculture Organization of the United Nations. FAO STAT,http://faostat.fao.org/site/339/default.aspx (accessed 20 Jul2015)(2012).

101 Mehta PK. Properties of blended cements made from rice husk ash. Am Concr Inst J;74:440-442 (1977).

102 Malhotra VM, Mehta PK. Pozzolanic and Cementitious Materials. 1st ed. Taylor \& Francis: New York, 1996.

103 Della VP, Kühn I, Hotza D. Rice husk ash as an alternate source for active silica production. Mater Lett;57: 818-821 (2002).

104 Abreu RF, Schneider J, Cincotto MA. Structure and hydration kinetics of silica particles in rice husk ash studied by ${ }^{29} \mathrm{Si}$ high-resolution nuclear magnetic 
resonance. J Am Ceram Soc;88: 1514-1520 (2005).

105 Detphan S, Chindaprasirt P. Preparation of fly ash and rice husk ash geopolymer. Int J Miner Metall Mater;16: 720-726 (2009).

106 Rattanasak U, Chindaprasirt P, Suwanvitaya P. Development of high volume rice husk ash alumino silicate composites. Int J Miner Metall Mater;17: 654659 (2010).

107 He J, Jie Y, Zhang J, Yu Y, Zhang G. Synthesis and characterization of red mud and rice husk ash-based geopolymer composites. Cem Concr Compos;37: 108-118 (2013).

108 Gastaldini ALG, Isaia GC, Gomes NS, Sperb JEK. Chloride penetration and carbonation in concrete with rice husk ash and chemical activators. Cem Concr Compos;29: 176-180 (2007).

109 Bernal SA, Rodríguez ED, Mejia de Gutiérrez R, Provis JL, Delvasto S. Activation of metakaolin/slag blends using alkaline solutions based on chemically modified silica fume and rice husk ash. Waste Biomass Valoriz;3:99-108 (2011).

110 Mejía JM, Mejía de Gutiérrez R, Puertas F. Rice husk ash as a source of silica in alkali-activated fly ash and granulated blast furnace slag systems. Mater Constr; 63: 361-375 (2013).

111 Bouzón N, Payá J, Borrachero MV, Soriano L, Tashima MM, Monzó J. Refluxed rice husk ash $/ \mathrm{NaOH}$ suspension for preparing alkali activated binders. Mater Lett; 115: 72-74 (2014).

112 Bernal-SA, Rodríguez ED, Mejía de Gutiérrez R, Provis JL. Performance at high temperature of alkali-activated slag pastes produced with silica fume and rice husk ash based activators.Mater Constr; 65:article e049 (2015).

113 Villaquirán-Caicedo M, Rodriguez E, Mejía de Gutiérrez R. Evaluación microestructural de geopolímeros basados en metacaolín y fuentes alternativas de sílice expuestos a temperaturas altas. Microstructural assessment of metakaolin-based geopolymers produced with alternative silica sources exposed to high temperat. Ing Investig Tecnol;16: 113-122 (2015).

114 Tay J-H. Ash from oil-palm waste asaconcrete material. J Mater Civ Eng;2: 94-105 (1990).

115 Foo KY, Hameed BH. Value-added utilization of oil palm ash: a superior recycling of the industrial agricultural waste. $J$ Hazard Mater;172: 523-31 (2009).

116 Tangchirapat W, Saeting T, Jaturapitakkul C, Kiattikomol K, Siripanichgorn A. Use of waste ash from palm oil industry in concrete. Waste Manag;27: 81-8 (2007).

117 Fazal A, Fancey KS. Performance enhancement of nylon kevlar fiber composites through viscoelastically generated pre-stress.Polym Polym Compos; 16: 101-113 (2008).

118 Salih MA, Farzadnia N, Abang Ali AA, Demirboga R. Effect of different curing temperatures on alkali activated palm oil fuel ash paste. Constr Build Mater;94: 116-125 (2015).

119 Yusuf MO, Megat Johari MA, Ahmad ZA, Maslehuddin M. Strength and

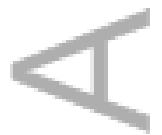


microstructure of alkali-activated binary blended binder containing palm oil fuel ash and ground blast-furnace slag. Constr Build Mater;52: 504-510 (2014).

120 Yusuf MO, Megat Johari MA, Ahmad ZA, Maslehuddin M. Evolution of alkaline activated ground blast furnace slag-ultrafine palm oil fuel ash based concrete. Mater Des;55: 387-393 (2014).

121 Islam A, Alengaram UJ, Jumaat MZ, Bashar II. The development of compressive strength of ground granulated blast furnace slag-palm oil fuel ashfly ash based geopolymer mortar. Mater Des;56: 833-841 (2014).

122 Yusuf MO, Azmi M, Johari M, Ahmad ZA, Maslehuddin M. Evaluation of slag-blended alkaline-activated palm oil fuel ash mortar exposed to the sulfuric

acid environment. J Mater Civ Eng; 27:article 04015058(2015).

123 Ranjbar N, Mehrali M, Behnia A, Alengaram UJ, Jumaat MZ. Compressive strength and microstructural analysis of fly ash/palm oil fuel ash based geopolymer mortar. Mater Des;59: 532-539 (2014).

124 Ranjbar N, Mehrali M, Alengaram UJ, Metselaar HSC, Jumaat MZ. Compressive strength and microstructural analysis of fly ash/palm oil fuel ash based geopolymer mortar under elevated temperatures. Constr Build Mater;65: 114-121 (2014).

125 Ariffin MAM, Bhutta MAR, Hussin MW, Mohd Tahir M, Aziah N. Sulfuric acid resistance of blended ash geopolymer concrete. Constr Build Mater;43: 80-86 (2013).

126 Kupaei RH, Alengaram UJ, Jumaat MZ Bin, Nikraz H. Mix design for fly ash based oil palm shell geopolymer lightweight concrete. Constr Build Mater;43: 490-496 (2013).

127 Liu MYJ, Alengaram UJ, Jumaat MZ, Mo KH. Evaluation of thermal conductivity, mechanical and transport properties of lightweight aggregate foamed geopolymer concrete. Energy Build;72: 238-245 (2014).

128 Hawa A, Tonnayopas D, Prachasaree W. Performance evaluation and microstructure characterization of metakaolin-based geopolymer containing oil palm ash. Sci World J;2013: article 857586 (2013).

129 The Statistics Portal (statista). World sugar cane production from 1965 to 2013. http://www.statista.com/statistics/249604/sugar-cane-production-worldwide/ (accessed 20 Jul2015)(2013).

130 van Oss H. 2012 Minerals yearbook. Cement. U.S. Geological Survey: Washington DC(2015).

$131 \mathrm{FAO} /$ Food and Agriculture Organization of the United Nations. Statistics Division. Production.http://faostat.fao.org (accessed 1 Sep2015)(2013).

132 United Nations. World population prospects, the 2015 Revision. PopulationDivision.http://esa.un.org/unpd/wpp/DataQuery/ (2015).

133 Austin A. Bagasse power.Biomass Magazine.http://biomassmagazine.com/articles/5247/bagasse-power, article 5247(2011).

134 Pandey A, Soccol CR, Nigam P, Soccol VT. Biotechnological potential of agro-industrial residues. I: sugarcane bagasse. Bioresourc Technol;74: 69- 
80(2000).

135 Ganesan K, Rajagopal K, Thangavel K. Evaluation of bagasse ash as supplementary cementitious material. Cem Concr Compos;29: 515-524 (2007).

136 Morales EV, Villar-Cociña E, Frías M, Santos SF, Savastano H. Effects of calcining conditions on the microstructure of sugar cane waste ashes (SCWA): Influence in the pozzolanic activation. Cem Concr Compos;31: 22-28 (2009).

137 Cordeiro GC, Toledo Filho RD, Fairbairn EMR. Effect of calcination temperature on the pozzolanic activity of sugar cane bagasse ash. Constr Build Mater;23: 3301-3303 (2009).

138 Cordeiro GC, Toledo Filho RD, Tavares LM, Fairbairn EDMR. Ultrafine grinding of sugar cane bagasse ash for application as pozzolanic admixture in concrete. Cem Concr Res;39: 110-115 (2009).

139 Cordeiro GC, Toledo Filho RD, Tavares LM, Fairbairn EMR. Experimental characterization of binary and ternary blended-cement concretes containing ultrafine residual rice husk and sugar cane bagasse ashes. Constr Build Mater;29: 641-646 (2012).

140 Fairbairn EMR, Americano BB, Cordeiro GC, Paula TP, Toledo Filho RD, Silvoso MM. Cement replacement by sugar cane bagasse ash: $\mathrm{CO}_{2}$ emissions reduction and potential for carbon credits. J Environ Manag;91: 1864-1871 (2010).

141 Castaldelli V, Akasaki J, Melges J, Tashima M, Soriano L, Borrachero M et al. Use of slag/sugar cane bagasse ash (SCBA) blends in the production of alkaliactivated materials. Materials (Basel);6: 3108-3127 (2013).

142 Castaldelli VN, Tashima MM, Melges JLP, Akasaki JL, Monzó JM, Borrachero MV et al.Preliminary studies on the use of sugar cane bagasse ash (SCBA) in the manufacture of alkali activated binders. Key Eng Mater;600: 689-698 (2014).

143 Pereira A, Akasaki JL, Melges JLP, Tashima MM, Soriano L, Borrachero M V. et al. Mechanical and durability properties of alkali-activated mortar based on sugarcane bagasse ash and blast furnace slag. Ceram Int; 41: 13012-13024 (2015)

144 Gräfe M, Power G, Klauber C. Bauxite residue issues: III. Alkalinity and associated chemistry. Hydrometall;108: 60-79 (2011).

145 Pontikes Y, Angelopoulos GN. Bauxite residue in cement and cementitious applications: Current status and a possible way forward. Resourc Conserv Recyc;73: 53-63 (2013).

146 Wagh AS, Douse VE. Silicate bonded unsintered ceramics of Bayer process waste. J Mater Res;6: 1094-1102 (1991).

147 Dimas DD, Giannopoulou IP, Panias D. Utilization of alumina red mud for synthesis of inorganic polymeric materials. Miner Process Extr Metall Rev;30: 211-239 (2009).

148 Srikanth S, Ray AK, Bandopadhyay A, Ravikumar B, Jha A. Phase constitution during sintering of red mud and red mud-fly ash mixtures. $\mathrm{J} \mathrm{Am}$ Ceram Soc;88: 2396-2401 (2005).

149 Chen X, Lu A, Qu G. Preparation and characterization of foam ceramics from 
red mud and fly ash using sodium silicate as foaming agent. Ceram Int;39: 1923-1929 (2013).

150 Kumar A, Kumar S. Development of paving blocks from synergistic use of red mud and fly ash using geopolymerization. Constr Build Mater;38: 865-871 (2013).

151 Pan Z, Fang Y, Zhao C. Research on alkali activated slag-red mud cement preparation. Bull Chin Ceram Soc;18: 34-39 (1999).

152 Pan Z, Li D, Yu J, Yang N. Properties and microstructure of the hardened alkali-activated red mud-slag cementitious material. Cem Concr Res;33: 14371441 (2003).

153 Ye N, Yang J, Ke X, Zhu J, Li Y, Xiang C et al. Synthesis and characterization of Geopolymer from Bayer red mud with thermal pretreatment. J Am Ceram Soc;97: 1652-1660 (2014).

154 Ye N, Zhu J, Liu J, Li Y, Ke X, Yang J. Influence of thermal treatment on phase transformation and dissolubility of aluminosilicate phase in red mud. Mater Res Soc Symp Proc;1488:doi:10.1557/opl.2012.1546 (2012).

155 Ke X, Bernal SA, Ye N, Provis JL, Yang J. One-Part Geopolymers based on thermally treated red mud/NaOH blends. J Am Ceram Soc;98: 5-11 (2015).

156 Index mundi. Kaolin production by country. http://www.indexmundi.com/minerals/?product=kaolin\&graph=production (accessed 15 Jul2015)(2007).

157 Murray $\mathrm{HH}$, Alves CA, Bastos $\mathrm{CH}$. Mining, processing and applications of the Capim Basin kaolin, Brazil. Clay Miner;42: 145-151 (2007).

158 Prasad MS, Reid KJ, Murray HH. Kaolin: processing, properties and applications. Appl Clay Sci;6: 87-119(1991).

159 Barata MS, Angélica RS. Caracterização dos resíduos cauliníticos das indústrias de mineração de caulim da amazônia como matéria-prima para produção de pozolanas de alta reatividade. Cerâmica;58: 36-42 (2012).

160 Ingunza MPD, Júnior OFS, Costa CG. Recycling of kaolin processing waste as aggregate in asphalt concrete. Adv Mater Res;717: 21-26 (2013).

161 Frías M, la Villa RV, Rojas MS, Medina C, Juan Valdés A. Scientific aspects of kaolinite based coal mining wastes in pozzolan $/ \mathrm{Ca}(\mathrm{OH})_{2}$ system. $J \mathrm{Am}$ Ceram Soc;95: 386-391 (2012).

162 Nóbrega-de-Azeredo A, Struble L, Carneiro A. Microstructural characteristics of lime-pozzolan pastes made from kaolin production wastes. Mater Struct;48:2123-2132 (2014).

163 Maia AAB, Angelica RS, Neves RF. Use of industrial kaolin waste from the Brazilian Amazon region for synthesis of zeolite A. Clay Miner;46: 127-136 (2011).

164 Hildebrando EA, Angélica RS, Neves RF, Valenzuela-Diaz FR. Síntese de zeólita do tipo faujasita a partir de um rejeito de caulim. Cerâmica;58: 453-458 (2012).

165 Longhi MA, Rodriguez ED, Bernal SA, Provis JL, Kirchheim AP. Effect of thermal curing in geopolymers based on calcinated kaolin sludge. In: XIII encontro da SBPMat. João Pessoa, Brazil(2014). 
166 Longhi MA, Rodríguez ED, Bernal SA, Provis JL, Kirchheim AP. Valorisation of a kaolin mining waste for the production of geopolymers. J Clean Prod; 115: 265-272 (2016).

167 He C, Makovicky E, Øsbæck B. Thermal stability and pozzolanic activity of calcined illite. Appl Clay Sci;9: 337-354 (1995).

168 He C, Osbaeck B, Makovicky E. Pozzolanic reactions of six principal clay minerals: Activation, reactivity assessments and technological effects. Cem Concr Res;25: 1691-1702 (1995).

169 Buchwald A, Hohmann M, Posern K, Brendler E. The suitability of thermally activated illite/smectite clay as raw material for geopolymer binders. Appl Clay Sci;46: 300-304 (2009).

170 Snellings R, Mertens G, Elsen J. Supplementary cementitious materials.Rev Miner Geochem;74: 211-278 (2012).

171 Lemougna PN, Madi AB, Kamseu E, Melo UC, Delplancke M-P, Rahier H. Influence of the processing temperature on the compressive strength of $\mathrm{Na}$ activated lateritic soil for building applications. Constr Build Mater;65: 60-66 (2014).

172 Ambroise J, Murat M, Péra J. Hydration reaction and hardening of calcined clays and related minerals V. Extension of the research and general conclusions. Cem Concr Res;15: 261-268 (1985).

173 Marwan T, Pera J, Ambroise J. Action of some aggressive solutions on Portland and calcined laterite blended cement concretes. Am Concr Inst Spec Publ;132: 763-780 (1992).

174 Silva-Neto J, Gomes KC, Lima-Filho MRF, Porto-Vieira AA, Torres SM. Alkaline activation of natural iron containing precursors. In: 34th Annual Cement and Concrete Science Conference. Sheffield, UK (2014).

175 Gomes KC, Torres SM, da Silva ZE, Perazzo-Barbosa N, Lima-Filho MRF. Alkaline activation of aluminum and iron rich precursors. Key Eng Mater;600: 329-337 (2014).

176 Mcintosh A, Lawther SEM, Kwasny J, Soutsos MN, Cleland D, Nanukuttan S. Selection and characterisation of geological materials for use as geopolymer precursors. Adv Appl Ceram; 114: 378-385 (2015).

177 Lassinantti Gualtieri M, Romagnoli M, Pollastri S, Gualtieri AF. Inorganic polymers from laterite using activation with phosphoric acid and alkaline sodium silicate solution: Mechanical and microstructural properties. Cem Concr Res;67: 259-270 (2015).

178 Perera DS, Hanna J V., Davis J, Blackford MG, Latella BA, Sasaki Y et al. Relative strengths of phosphoric acid-reacted and alkali-reacted metakaolin materials. J Mater Sci;43: 6562-6566 (2008).

179 Ahmad S, Barbhuiya SA, Elahi A, Iqbal J. Effect of Pakistani bentonite on properties of mortar and concrete. Clay Miner;46: 85-92 (2011).

180 Taylor-Lange SC, Lamon EL, Riding KA, Juenger MCG. Calcined kaolinitebentonite clay blends as supplementary cementitious materials. Appl Clay Sci;108: 84-93 (2015).

181 Hu M, Zhu X, Long F. Alkali-activated fly ash-based geopolymers with zeolite 
or bentonite as additives. Cem Concr Compos;31: 762-768 (2009).

182 Chervonnyi AD, Chervonnaya NA. Geopolymeric agent for immobilization of radioactive ashes after biomass burning. Radiochemistry;45: 182-188 (2003).

183 García-Lodeiro I, Cherfa N, Zibouche F, Fernández-Jiménez A., Palomo A. The role of aluminium in alkali-activated bentonites. Mater Struct;48: 585-597 (2014).

184 Silva I, Castro-Gomes JP, Albuquerque A. Effect of immersion in water partially alkali-activated materials obtained of tungsten mine waste mud. Constr Build Mater;35: 117-124 (2012).

185 Southam DC, Brent GF, Felipe F, Carr C, Hart RD. Towards more sustainable minefills - Replacement of ordinary Portland cement with geopolymer cement. Publ Austr Inst Mining Metall;9, 157-164 (2007).

186 Pacheco-Torgal F, Castro-Gomes J, Jalali S. Properties of tungsten mine waste geopolymeric binder. Constr Build Mater;22: 1201-1211 (2008).

187 Pacheco-Torgal F, Castro-Gomes JP, Jalali S. Investigations on mix design of tungsten mine waste geopolymeric binder. Constr Build Mater;22: 1939-1949 (2008).

188 Pacheco-Torgal F, Jalali S. Influence of sodium carbonate addition on the thermal reactivity of tungsten mine waste mud based binders. Constr Build Mater;24: 56-60 (2010).

189 Ahmari S, Zhang L. Production of eco-friendly bricks from copper mine tailings through geopolymerization. Constr Build Mater;29: 323-331 (2012).

190 Ahmari S, Zhang L, Zhang J. Effects of activator type/concentration and curing temperature on alkali-activated binder based on copper mine tailings. $J$ Mater Sci;47: 5933-5945 (2012).

191 Ahmari S, Zhang L. Durability and leaching behavior of mine tailings-based geopolymer bricks. Constr Build Mater;44: 743-750 (2013).

192 Zhang L, Ahmari S, Zhang J. Synthesis and characterization of fly ash modified mine tailings-based geopolymers. Constr Build Mater;25: 3773-3781 (2011).

193 Ahmari S, Parameswaran K, Zhang L, Asce M. Alkali activation of copper mine tailings and low-calcium flash-furnace copper smelter slag. J Mater Civ Eng;27: article 04014193 (2015).

194 Ren X, Zhang L, Ramey D, Waterman B, Ormsby S. Utilization of aluminum sludge (AS) to enhance mine tailings-based geopolymer. J Mater Sci;50: 13701381 (2014).

195 Caballero E, Sánchez W, Ríos CA. Synthesis of geopolymers from alkaline activation of gold mining wastes. Ing y Compet;16: 317-330 (2014).

196 Barrie E, Cappuyns V, Vassilieva E, Adriaens R, Hollanders S, Garcés D et al. Potential of inorganic polymers (geopolymers) made of halloysite and volcanic glass for the immobilisation of tailings from gold extraction in Ecuador. Appl Clay Sci;109-110: 95-106 (2015).

197 World Coal Association. Coal Statistics. WCA: London (2012).

198 Asokan P, Saxena M, Asolekar SR. Coal combustion residues - environmental implications and recycling potentials. Resourc Conserv Recyc;43: 239-262 
(2005).

199 Sajwan KS, Punshon T, Seaman JC. Production of coal combustion products and their potential uses. In: Sajwan K, Twardowska I, Punshon T, Alva A (eds). Coal Combustion Byproducts and Environmental Issues SE - 1. Springer: New York, pp. 3-9 (2006).

200 Bijen J. Benefits of slag and fly ash. Constr Build Mater 1996; 10: 309-314.

201 Ecoba/European Coal Combustion Products Association. Production and utilisation of CCPs in 2010 in Europe (EU15).http://www.ecoba.org/evjm,media/ccps/ECO-STAT_2010.pdf (accessed 22 Jul2015)(2010).

202 ACAA/American Coal Ash Association. 2012 Coal combustion product (CCP) production \& use survey report.http://www.acaausa.org/Portals/9/Files/PDFs/revisedFINAL2012CCPSurveyReport.pdf (accessed 21 Jul2015)(2012).

20340 CFR Parts 257 and 261. Hazardous and solid waste management system; disposal of coal combustion residuals from electric utilities; Final Rule. US Government: Washington DC(2015).

204 Singh M, Siddique R. Properties of concrete containing high volumes of coal bottom ash as fine aggregate. J Clean Prod;91: 269-278 (2015).

205 Singh M, Siddique R. Compressive strength, drying shrinkage and chemical resistance of concrete incorporating coal bottom ash as partial or total replacement of sand. Constr Build Mater;68: 39-48 (2014).

206 Cheriaf M, Rocha JC, Péra J. Pozzolanic properties of pulverized coal combustion bottom ash. Cem Concr Res;29: 1387-1391 (1999).

207 Jaturapitakkul C, Cheerarot R. Development of bottom ash as pozzolanic material. J Mater Civ Eng;15: 48-53 (2003).

208 Chindaprasirt P, Jaturapitakkul C, Chalee W, Rattanasak U. Comparative study on the characteristics of fly ash and bottom ash geopolymers. Waste Manag;29: 539-543 (2009).

209 Sathonsaowaphak A, Chindaprasirt P, Pimraksa K. Workability and strength of lignite bottom ash geopolymer mortar. J Hazard Mater; 168: 44-50 (2009).

210 Sata V, Sathonsaowaphak A, Chindaprasirt P. Resistance of lignite bottom ash geopolymer mortar to sulfate and sulfuric acid attack. Cem Concr Compos;34: 700-708 (2012).

211 Chotetanorm C, Chindaprasirt P. High-calcium bottom ash geopolymer: sorptivity, pore size, and resistance to sodium sulfate attack. J Mater Civ Eng;25: 105-111 (2012).

212 Geetha S, Ramamurthy K. Properties of geopolymerised low-calcium bottom ash aggregate cured at ambient temperature. Cem Concr Compos;43: 20-30 (2013).

213 Monte MC, Fuente E, Blanco A, Negro C. Waste management from pulp and paper production in the European Union. Waste Manag;29: 293-308 (2009).

214 Skogs Industrierna. Swedish Forest Industries Federation. Global paper production

by region.http://www.forestindustries.se/documentation/statistics_ppt_files/interna 
tional/global-paper-production-by-region (accessed 20 Jul2015)(2014).

215 García R, Vigil de la Villa R, Vegas I, Frías M, Sánchez de Rojas MI. The pozzolanic properties of paper sludge waste. Constr Build Mater;22: 14841490 (2008).

216 Frías M, García R, Vigil R, Ferreiro S. Calcination of art paper sludge waste for the use as a supplementary cementing material. Appl Clay Sci;42: 189-193 (2008).

217 Yan S, Sagoe-Crentsil K. Properties of wastepaper sludge in geopolymer mortars for masonry applications. J Environ Manag;112: 27-32 (2012).

218 Antunes Boca Santa RA, Bernardin AM, Riella HG, Kuhnen NC. Geopolymer synthetized from bottom coal ash and calcined paper sludge. $J$ Clean Prod;57: 302-307 (2013).

219 Gluth GJG, Lehmann C, Rübner K, Kühne H-C. Reaction products and strength development of wastepaper sludge ash and the influence of alkalis. Cem Concr Compos;45: 82-88 (2014).

220 Bernal SA, Ball R, Hussein O, Heath A, Provis JL. Paper sludge ash as a precursor for production of alkali-activated materials. In: Proceedings of the Second International Conference on Advances in Chemically-Activated Materials (CAM'2014). RILEM: Changsha, China(2014).

221 Pacewska B, WiliDska I, Bukowska M, NocuDWczelik W. Effect of waste aluminosilicate material on cement hydration and properties of cement mortars. Cem Concr Res;32: 1823-1830 (2002).

222 Payá J, Monzó J, Borrachero M V. Fluid catalytic cracking catalyst residue (FC3R) An excellent mineral by-product for improving early-strength development of cement mixtures. Cem Concr Res;29: 1773-1779 (1999).

223 Pacewska B, WiliDska I, Kubissa J. Use of spent catalyst from catalytic cracking in fluidized bed as a new concrete additive. Thermochim Acta;322: 175-181 (1998).

224 Fuel - The Global Business of Fuels. Global demand for catalytic technology increases. http://www.hartfuel.com/f.catalyst.html (accessed 15 Jul2015).

225 Bare SR, Charochak ME, Kelly SD, Lai B, Wang J, Chen-Wiegart YK. Characterization of a fluidized catalytic cracking catalyst on ensemble and individual particle level by p-ray micro- and panotomography, micro-X-ray fluorescence, and micro-X-ray diffraction. ChemCatChem Catal;6: 1427-1437 (2014).

226 Tashima MM, Akasaki JL, Castaldelli VN, Soriano L, Monzó J, Payá J et al. New geopolymeric binder based on fluid catalytic cracking catalyst residue (FCC). Mater Lett; 80:50-52 (2012).

227 Tashima MM, Akasaki JL, Melges JLP, Soriano L, Monzó J, Payá J et al. Alkali activated materials based on fluid catalytic cracking catalyst residue (FCC): Influence of $\mathrm{SiO}_{2} / \mathrm{Na}_{2} \mathrm{O}$ and $\mathrm{H}_{2} \mathrm{O} / \mathrm{FCC}$ ratio on mechanical strength and microstructure. Fuel;108: 833-839 (2013).

228 Rodríguez ED, Bernal SA, Provis JL, Gehman JD, Monzó JM, Payá J et al.Geopolymers based on spent catalyst residue from a fluid catalytic cracking (FCC) process. Fuel;109: 493-502 (2013). 
229 Trochez JJ, Mejía de Gutiérrez R, Rivera J, Bernal SA. Synthesis of geopolymer from spent FCC: Effect of $\mathrm{SiO}_{2} / \mathrm{Al}_{2} \mathrm{O}_{3}$ and $\mathrm{Na}_{2} \mathrm{O} / \mathrm{SiO}_{2}$ molar ratios. Mater Constr;65: article e046 (2015).

230 Natural Resources Wales/Cymru CNSEPA (SEPA), Northern Ireland Environment Agency (NIEA), UK Environment Agency. Technical Guidance WM3: Waste Classification - Guidance on the classification and assessment of waste.(2015).

231 Margallo M, Taddei MBM, Hernández-pellón A, Aldaco R, Irabien Á. Environmental sustainability assessment of the management of municipal solid waste incineration residues: a review of the current situation. Clean Technol Environ Policy; 17: 1333-1353 (2015).

232 National Bureau of Statistics of China. 25-11. Basic Statistics on Urban Sanitation in Cities by Region. China Statistical Year Book 2014 (2014).

233 Zuo J, Xia B, Zillante G, Zhao Z. Estimating the amount of building-Related construction and demolition waste in China. In: Proceedings of the 17th International Symposium on Advancement of Construction Management and Real Estate. Berlin, pp 91-98 (2014).

234 Townsend T, Wilson C, Beck B. The Benefits of Construction and Demolition Materials Recycling in the United States. Construction \& Demolition Recycling Association: Aurora, IL (2014).

235 Silvestre R, Medel E, García A, Navas J. Using ceramic wastes from tile industry as a partial substitute of natural aggregates in hot mix asphalt binder courses. Constr Build Mater; 45: 115-122 (2013).

236 FAO/Food and Agriculture Organization of the United Nations. AQUA STAT. Database.

2016.http://www.fao.org/nr/water/aquastat/data/query/index.html?lang=en (accessed 1 Jan2016).

237 Mateo-sagasta J, Raschid-sally L, Thebo A. Global wastewater and sludge production, treatment and use. In: Drechel P, Qadir M, Wichelns D (eds). Wastewater. Economic Asset in an Urbanizing World. Springer: New York, 2015, pp 15-38.

238 FEVE: The European Container Glass Federation. EU container glass production shows industry resilience. Statistics (Ber). 2013.http://www.feve.org/index.php?option=com_content\&view=article\&id=1 0\&Itemid $=11$ (accessed 1 Jan2015).

239 U.S. Environmental Protection Agency. Glass. EPA: Washington DC (2015).

240 United States Department of Agriculture, Foreign Agriculture Services. Palm oil: World supply and distribution. https://apps.fas.usda.gov/psdonline/psdReport.aspx?hidReportRetrievalName= Table $+11 \% 3 \mathrm{a}+$ Palm + Oil $\% 3 \mathrm{a}+$ World + Supply + and + Distribution\&hidReportRe trievalID=710\&hidReportRetrievalTemplateID=8 (accessed 1 Jan2016) (2015).

241 Pontikes Y, Angelopoulos GN. Bauxite residue in cement and cementitious applications: Current status and a possible way forward. Resour Conserv Recycl; 73: 53-63 (2013). 
242 Barata MS, Angélica RS. Caracterização dos resíduos cauliníticos das indústrias de mineração de caulim da amazônia como matéria-prima para produção de pozolanas de alta reatividade. Cerâmica; 58: 36-42 (2012).

243 Kim HK. Utilization of sieved and ground coal bottom ash powders as a coarse binder in high-strength mortar to improve workability. Constr Build Mater; 91: 57-64 (2015).

244 Environment Agency UK. Waste Protocols Project: Paper sludge ash. A technical report on the production and use of paper sludge ash. Banbury, UK (2008).

245 Frías M, Rodríguez O, Sánchez De Rojas MI. Paper sludge, an environmentally sound alternative source of MK-based cementitious materials. A review. Constr Build Mater; 74: 37-48 (2015).

246 Marafi. M, Stanislaus A, Furimsky E. Handbook of spent hydroprocessing catalyst: regeneration, rejuvenation, reclamation, environment and safety. 1 st ed. Elsevier: Amsterdam (2010).

247 Fernández-Jiménez A, Palomo A. Characterisation of fly ashes. Potential reactivity as alkaline cements. Fuel; 82: 2259-2265 (2003).

248 van Jaarsveld JGS, van Deventer JSJ. Effect of the alkali metal activator on the properties of fly ash-based geopolymers. Ind Eng Chem Res; 38: 3932-3941 (1999).

249 Tennakoon C, Sagoe-Crentsil K, San Nicolas R, Sanjayan JG. Characteristics of Australian brown coal fly ash blended geopolymers. Constr Build Mater; 101: 396-409 (2015).

250 Mejía JM, Rodríguez E, Mejía de Gutiérrez R, Gallego N. Preparation and characterization of a hybrid alkaline binder based on a fly ash with no commercial value. J Clean Prod; : 346-352 (2015).

251 Rivera JF, Mejía de Gutiérrez R, Mejia JM, Gordillo M. Hybrid cement based on the alkali activation of by-products of coal / Cementos híbridos basados en la activación alcalina de subproductos del carbón. J Constr; 13: 31-39 (2014).

252 Li Q, Xu H, Li F, Li P, Shen L, Zhai J. Synthesis of geopolymer composites from blends of CFBC fly and bottom ashes. Fuel; 97: 366-372 (2012).

253 Topçu OB, Toprak MU. Properties of geopolymer from circulating fluidized bed combustion coal bottom ash. Mater Sci Eng A; 528: 1472-1477 (2011).

254 Pimraksa K, Chindaprasirt P, Huanjit T, Tang C, Sato T. Cement mortars hybridized with zeolite and zeolite-like materials made of lignite bottom ash for heavy metal encapsulation. J Clean Prod; 41: 31-41 (2013).

255 Topçu OB, Toprak MU, Uyguno lu T. Durability and microstructure characteristics of alkali activated coal bottom ash geopolymer cement. J Clean Prod; 81: 211-217 (2014).

256 Luna Galiano Y, Fernández Pereira C, Vale J. Stabilization/solidification of a municipal solid waste incineration residue using fly ash-based geopolymers. $J$ Hazard Mater; 185: 373-81 (2011).

257 Lancellotti I, Ponzoni C, Barbieri L, Leonelli C. Alkali activation processes for incinerator residues management. Waste Manag; 33: 1740-9 (2013).

258 Ogundiran MB, Nugteren HW, Witkamp GJ. Immobilisation of lead smelting 
slag within spent aluminate-fly ash based geopolymers. J Hazard Mater; 248249: 29-36 (2013).

259 Nugteren HW, Ogundiran MB, Witkamp G, Kreutzer MT. Coal fly ash activated by waste sodium aluminate solutions as an immobilizer for hazardous waste. In: 2011 World of Coal Ash (WOCA) Conference. Denver, CO. (2011).

260 Phair JW, van Deventer JSJ. Characterization of fly-ash-based geopolymeric binders activated with sodium aluminate. Ind Eng Chem Res; 41: 4242-4251 (2002).

261 Van Riessen A, Jamieson E, Kealley CS, Hart RD, Williams RP. Bayergeopolymers: an exploration of synergy between the alumina and geopolymer industries. Cem Concr Compos; 41: 29-33 (2013).

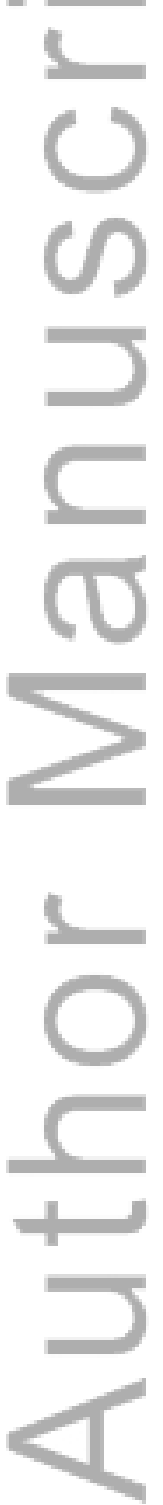




\section{University Library}

\section{- M M N E R VA A gateway to Melbourne's research publications}

Minerva Access is the Institutional Repository of The University of Melbourne

Author/s:

Bernal, SA;Rodriguez, ED;Kirchheim, AP;Provis, JL

Title:

Management and valorisation of wastes through use in producing alkali-activated cement materials

Date:

2016-09-01

\section{Citation:}

Bernal, S. A., Rodriguez, E. D., Kirchheim, A. P. \& Provis, J. L. (2016). Management and valorisation of wastes through use in producing alkali-activated cement materials. JOURNAL OF CHEMICAL TECHNOLOGY AND BIOTECHNOLOGY, 91 (9), pp.2365-2388. https:// doi.org/10.1002/jctb.4927.

Persistent Link:

http://hdl.handle.net/11343/291110 